\title{
Sustainable utilization of Gyrinops walla Gaetner: in vitro production of sesquiterpenes by chemical and biological elicitation
}

\author{
Sachithri Munasinghe ${ }^{1^{*}}$ (D) Seneviratnege Somaratne ${ }^{1}$, Shyama Weerakoon ${ }^{1}$ and Chandani Ranasinghe ${ }^{2}$
}

\begin{abstract}
Background: The recent recovery of Gyrinops walla as a potential producer of market-quality agarwood in mature damaged woods and branches has led to the intense illicit felling and exportation of $G$. walla leading to the verge of extinction from Sri Lankan flora. The sustainable utilization of $G$. walla undoubtedly enhances the foreign exchange of the country and the non-destructive utilization through tissue culture-based techniques is the only option available for sustainable exploitation and conservation of the vulnerable species. Healthy calli and cell suspensions were chemically and biologically elicited with salicylic acid (SA) and methyl jasmonate (MJ), and the sterilized fungal homogenate (carbohydrate equivalents) of Fusariym oxysporum, Phaeocremonium parasitica, Aspergillus niger, Trichoderma viride, Penicillium commune and Lasidiplodia theobromae fungal strains, respectively. The elicited calli and cell suspensions were harvested at different time periods to extract sesquiterpenes.

Results: Sesquiterpenes were produced in calli under chemical elicitors with media concentrations of $10 \mu \mathrm{M} \mathrm{SA}$, $100 \mu \mathrm{M} \mathrm{SA}, 10 \mathrm{mM} \mathrm{MJ}$ and $1 \mathrm{mM} \mathrm{MJ}$ and cell suspensions under $0.5 \mu \mathrm{M} \mathrm{SA}$ and $0.1 \mathrm{mM} \mathrm{MJ}$. Phaeocremonium parasitica, Trichoderma viride and Lasidiplodia theobromae were more effective in the production of sesquiterpenes in G. walla callus and cell suspension by biological elicitation.
\end{abstract}

Conclusion: The findings of the study led to the conclusion of the possibility of induction of production of sesquiterpenes through elicitation of G. walla calli and cell suspension in an in vitro system for sustainable utilization and conservation endeavours.

Keywords: Sesquiterpenes, Sustainability, Gyrinops walla, In vitro production, Artificial elicitation

\section{Background}

Gyrinops is a member of the Thymelaeaceae family [1], and similar to Aquilaria, Gyrinops is also classified as agarwood-producing trees [2]. Agarwood is a dark resinous substance, extremely appreciated in luxury perfumery and medicines. As a response to the stress of wounding and microbial infection, agarwood-producing species may activate their plant defence system triggering the production of agarwood that aids in suppressing

\footnotetext{
*Correspondence: sachujd@gmail.com

'Department of Botany, The Open University of Sri Lanka, Nawala, Sri Lanka Full list of author information is available at the end of the article
}

and localizing the infected area which helps the plant to resist or delay the infection by tylosis [3]. Fragrant compounds of agarwood are known to be sesquiterpenoids and chromone derivatives, which are the main source of agarwood's characteristic odour [4].

The products from naturally formed agarwood demand high economic value in the world fragrance market and the supply of agarwood from Southeast Asian countries is decreasing, agarwood from G. walla in Sri Lanka has drawn boundless attention from high-end users and traders. As a result, within 2013, the police and customs of Sri Lanka had confiscated 13,800 kg of 
processed agarwood chips [5] (www.dailynews.lk) and from 2015 to 2016, about 89,212 kg of agarwood chips has been confiscated when trying to export illegally for countries India, South Africa and United Arab Emirates [6]. In December 2012, the Biodiversity Secretariat of Sri Lanka re-categorized G. walla as "vulnerable" species according to IUCN Red List Categories [7] after which the export of timber, tissues or any extracts from the species was banned. Under these circumstances, there is a need for the conservation of this valuable species while avoiding artificial induction of agarwood which involves destructive harvesting and maintaining profitable export of agarwood from the country. Therefore, the application of plant biotechnological methods for sustainable utilization of Gyrinops walla is evident.

Callus and cell suspension culture systems are used nowadays for the large-scale production of plant cells from which secondary metabolites are extracted. The major advantage of cell culture is that synthesis of bioactive secondary metabolites is possible running in a controlled environment, independently from climate and soil conditions [8]. Cell cultures assist in two major ways in the production of plant secondary metabolites by yielding defined standard phytochemicals in large volumes and eliminating the presence of interfering compounds that occur in field-grown plants [9]. A few medicinally important alkaloids, anticancer drugs, recombinant proteins and food additives are produced in various cultures of plant cells and tissues in bioreactors. Developments made in the callus and cell culture have made the possibility of producing a wide range of medicinally important compounds such as alkaloids, terpenoids, steroids, saponins, phenolics, flavonoids and amino acids [10]. The first attempt to establish plant cell culture techniques for Aquilaria species was reported in 2005 by Qi et al. [11] which successfully established cell suspensions from root tissue obtained from in vitro germinated plantlets of $A$. sinensis, while Okudera and Ito [12] established cell suspension cultures using leaf tissue from seedlings of $A$. crassna, which had been germinated and grown in greenhouses. To date, no studies have been reported on the establishment of cell cultures and/ or production of secondary metabolites in Gyrinops walla. The present study reports the feasibility of in vitro producing sesquiterpenes using chemical and biological methods.

\section{Methods}

\section{Materials}

Based on the procedures followed by Okudera and Ito, [12] and Qi et al., [11], salicylic acid (SA) (Sigma Aldrich, USA) and methyl jasmonate (MJ) (Sigma Aldrich, USA) were chosen as the chemical elicitors.
The sterilized fungal homogenate (carbohydrate equivalents) was used as the elicitor. Pure cultures of the fungal strains of Fusariym oxysporum [13], Phaeocremonium parasitica [14], Aspergillus niger [15], Trichoderma viride [16], Penicillium commune [15] and Lasidiplodia thoebromae [15] were obtained from the Botany Laboratory, The Open University of Sri Lanka (OUSL), Nawala, Sri Lanka.

\section{Establishment of calli and cell suspensions}

Calli were raised according to Munasinghe et al. [17] and cell suspensions were initiated by placing $2 \mathrm{~g}$ of leafderived callus in a 50-mL conical flask containing $20 \mathrm{~mL}$ of liquid culture medium (MSM $+2.5 \mathrm{mg} / \mathrm{L} \mathrm{NAA}+0.5$ $\mathrm{mg} / \mathrm{l} \mathrm{BAP}$ ), without gelling agent and charcoal. It was placed on a shaker incubator (75-130 rpm) in continuous darkness and the total volume of liquid medium was gradually increased to $50 \mathrm{~mL}$ over a period of 3 weeks [12]. After 3 weeks, cell viability was tested using the 2, 3, 5-triphenyltetrazolium chloride (TTC) reduction method [18]. Once cell suspensions were established, they were sub-cultured at 3-week intervals in which 5 $\mathrm{mL}$ of cells (SCV - settled cell volume) was transferred into $100-\mathrm{mL}$ conical flasks containing $50 \mathrm{~mL}$ of liquid MSM. During each sub-culturing, large cell clumps were manually removed using sterile forceps and continuously sub-cultured until a uniform cell suspension was established. Once a uniform cell suspension line has been established, cell viability was tested using TTC [19].

\section{Chemical elicitation}

\section{Exposing callus culture to chemical elicitors}

The experiment was carried out in a Petri plate containing MS medium and each flask was started with about 2 $\mathrm{g}$ of fresh weight calli as the inoculum. SA was added to the MS medium supplemented with $30.0 \mathrm{~g} / \mathrm{L}$ sucrose, $100.0 \mathrm{mg} / \mathrm{L}$ myo-inositol, $10 \mathrm{~g} / \mathrm{L}$ agar, $0.5 \mathrm{mg} / \mathrm{L}$ BAP and $2.5 \mathrm{mg} / \mathrm{L}$ NAA with a final concentration of $10 \mu \mathrm{M}$ $(1.38 \mathrm{mg} / \mathrm{L})$ and $100 \mu \mathrm{M}(13.8 \mathrm{mg} / \mathrm{L})$, separately [12]. Based on [11], same procedure was repeated with MJ with a final concentration of $0.1 \mathrm{mM}(0.24 \mathrm{~g} / \mathrm{L}), 10 \mathrm{mM}$ $(2.24 \mathrm{~g} / \mathrm{L}), 100 \mathrm{mM}(22.4 \mathrm{~g} / \mathrm{L})$ and $1 \mathrm{M}(224.3 \mathrm{~g} / \mathrm{L})$, separately. The calli were incubated at $25^{\circ} \mathrm{C}$ in the dark for 2 to 16 weeks and harvested every 2 weeks for analysis by GC-MS. Visual observations were based on medium colour and sensory evaluation was by sniffing the flask immediately after incubation. All experiments were conducted in triplicate. Cell viability was accessed using the 2, 3, 5-triphenyltetrazolium chloride (TTC) reduction method during the incubation period.

\section{Exposing cell culture to chemical elicitors}

The experiment was carried out in a 100-mL Erlenmeyer flask containing $50 \mathrm{~mL}$ of fresh MS medium supplemented with $30.0 \mathrm{~g} / \mathrm{L}$ sucrose, $100.0 \mathrm{mg} / \mathrm{L}$ myo-inositol, 
$0.5 \mathrm{mg} / \mathrm{L}$ BAP and $2.5 \mathrm{mg} / \mathrm{L}$ NAA. Each flask was started with ca. $1 \mathrm{~g}$ of fresh weight 3-week-old cell suspension as the inoculum. The cells were grown in the dark on a rotary shaker at $100 \mathrm{rpm}$ for 10 days before treatments and the flasks with 10-day-old cell suspension were exposed to $\mathrm{MJ}$ by adding the concentrations of $0.05 \mathrm{mM}(11.2 \mathrm{mg} / \mathrm{L}), 0.1 \mathrm{mM}(22.4 \mathrm{mg} / \mathrm{L})$ and 0.15 $\mathrm{mM}(33.6 \mathrm{mg} / \mathrm{L})$ to the medium, separately $[11,20]$. Based on Okudera and Ito [12], the same procedure was repeated with SA with a final concentration of $0.25 \mu \mathrm{M}$ (34.2 $\mathrm{mg} / \mathrm{L}), 0.5 \mu \mathrm{M}(69 \mathrm{mg} / \mathrm{L})$ and $1 \mu \mathrm{M}(138 \mathrm{mg} / \mathrm{L})$, separately. The cultures were maintained in an orbital shaker at $25^{\circ} \mathrm{C}$ in the dark. Cells were harvested on different time durations $(0 \mathrm{~h}, 0.5 \mathrm{~h}, 2 \mathrm{~h}, 4 \mathrm{~h}, 6 \mathrm{~h}, 12 \mathrm{~h}, 24$ $\mathrm{h}$, and $72 \mathrm{~h}$ ). Visual observations were made on medium colour and sensory evaluation was also performed by sniffing the flask immediately after incubation. All experiments were conducted in triplicate. Cell viability was assessed using the 2, 3, 5-triphenyltetrazolium chloride (TTC) reduction method during the incubation period.

\section{Biological elicitation}

\section{Preparation of biological elicitors}

Biological elicitors were prepared according to the method described by Qi et al. [11]. All fungal genera were cultured on potato dextrose agar (PDA) (Oxoid, UK) and incubated at room temperature for 7 days. A 1- $\mathrm{cm}^{2}$ area of mycelium was cut and transferred into a 250-mL Erlenmeyer flask containing $100 \mathrm{~mL}$ of potato dextrose broth (Oxoid, UK) and incubated at room temperature at $100 \mathrm{rpm}$ shaking incubator for 3 weeks. Fully grown mycelia were collected by filtration using a Whatman filter paper (Grade 1) and washed twice in sterile distilled water. Mycelia were dried at $50{ }^{\circ} \mathrm{C}$ overnight followed by homogenization in liquid nitrogen using a mortar and pestle. The mixture was then dissolved in $100 \mathrm{~mL}$ of distilled water and left for $24 \mathrm{~h}$ at room temperature. Subsequently, it was dried in a rotary evaporator (Heidolph, UK) at $50{ }^{\circ} \mathrm{C}$ and autoclaved for 20 min at $121^{\circ} \mathrm{C}$. The autoclaved crude mycelial extract was used as the elicitor. The elicitor dose was measured by the total carbohydrate content of the fungal homogenate, which was determined by the phenol-sulphuric acid method using glucose as the standard [21].

\section{Exposing callus to biological elicitors}

The experiment was carried out in a Petri plate containing MS medium and each flask was started with about 2 $\mathrm{g}$ of fresh weight calli as the inoculum. Each fungal homogenate with the concentration of $25 \mathrm{mg} / \mathrm{L}, 50 \mathrm{mg} / \mathrm{L}, 75$ $\mathrm{mg} / \mathrm{L}$ and $100 \mathrm{mg} / \mathrm{L}$ was added, separately to MS medium supplemented with $30.0 \mathrm{~g} / \mathrm{L}$ sucrose, $100.0 \mathrm{mg} /$ $\mathrm{L}$ myo-inositol, agar $10 \mathrm{~g} / \mathrm{L}, 0.5 \mathrm{mg} / \mathrm{L} \mathrm{BAP}$ and $2.5 \mathrm{mg} / \mathrm{L}$ NAA. The calli were incubated at $25^{\circ} \mathrm{C}$ in the dark for 2

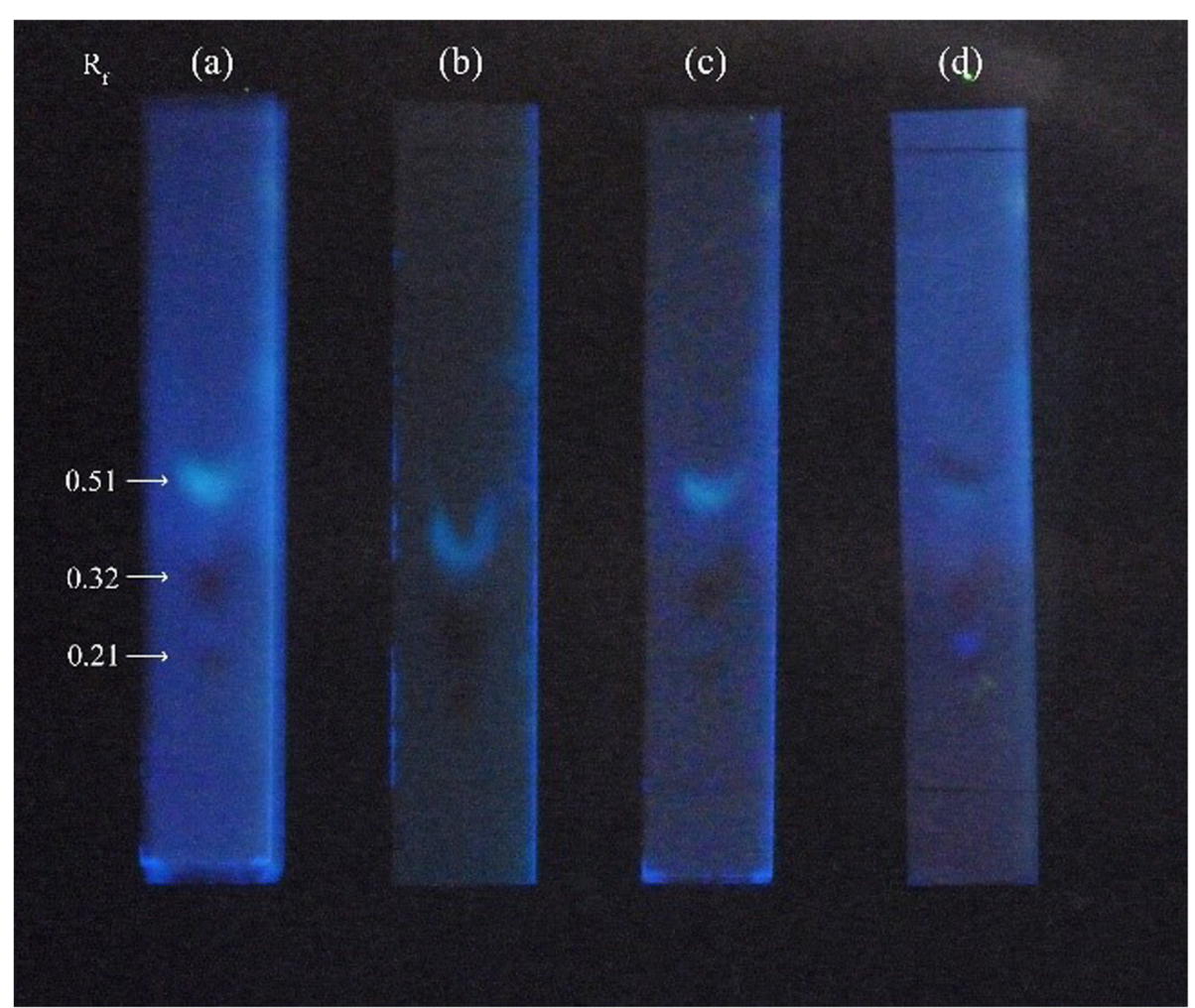

Fig. 1 TLC profiles resulting from the chemically elicited calli (a) SA $10 \mu \mathrm{M}$, (b) SA $100 \mu \mathrm{M}$, (c) MJ 1 mM and (d) MJ 10 mM on the 10 th week 
to 16 weeks and were harvested every 2 weeks for analysis by GC-MS. Visual observations were made on colour of the culture medium and sensory evaluation was achieved by sniffing the flask immediately after incubation. All experiments were conducted in triplicate. Cell viability was tested using the 2, 3, 5triphenyltetrazolium chloride (TTC) reduction method during the incubation period.

\section{Exposing cell suspension to biological elicitors}

The experiment was carried out in a 100-mL Erlenmeyer flask containing $50 \mathrm{~mL}$ of fresh MS medium supplemented with $30.0 \mathrm{~g} / \mathrm{L}$ sucrose, $100.0 \mathrm{mg} / \mathrm{L}$ myo-inositol, $0.5 \mathrm{mg} / \mathrm{L} \mathrm{BAP}$ and $2.5 \mathrm{mg} / \mathrm{L}$ NAA. Each flask was initiated with $c a .1 \mathrm{~g}$ of fresh weight 3 weeks old cell suspension as the inoculum. The cells were grown in the dark on a rotary shaker at $100 \mathrm{rpm}$ for 10 days before treatments. After 10 days of growth, fungal homogenates were added to the medium to final concentrations of 2 , $4,6,8$, and $10 \mathrm{mg} / \mathrm{L}$, separately. The cultures were maintained in an orbital shaker at $25{ }^{\circ} \mathrm{C}$ in dark. Cells were harvested on different time periods $(0 \mathrm{~h}, 0.5 \mathrm{~h}, 2 \mathrm{~h}, 4 \mathrm{~h}$, $6 \mathrm{~h}, 12 \mathrm{~h}, 24 \mathrm{~h}$, and $72 \mathrm{~h}$ ) following the treatment with fungal elicitors [16]. Visual observations were made on the colour of the medium and sensory evaluation was by sniffing the flask immediately after incubation. All experiments were conducted in triplicate. Cell viability was assessed using the 2, 3, 5-triphenyltetrazolium chloride (TTC) reduction method during the incubation period.

\section{Extraction of agarwood type constituents of elicited calli and cell suspensions}

Extraction of secondary metabolites in elicited calli and cell suspensions was carried out according to Jain et al. [22] modified with sonification. Harvested callus and cell suspension were dried at $50{ }^{\circ} \mathrm{C}$ in the oven overnight to a constant weight. The dried calli and cell suspensions were subsequently ground to a fine powder in liquid nitrogen, using a mortar and pestle. Approximately $5 \mathrm{~g}$ of the fine powder was transferred into a $50-\mathrm{mL}$ Erlenmeyer flask containing $10 \mathrm{~mL}$ of $100 \%$ hexane and incubated at room temperature at $150 \mathrm{rpm}$ shaking incubator for 3 days. Subsequently, the sample was sonicated using an ultrasonic water bath for $60 \mathrm{~min}$. The sample was centrifuged in $2500 \mathrm{~g}$ for $10 \mathrm{~min}$ and the supernatant was transferred to a new vessel. The

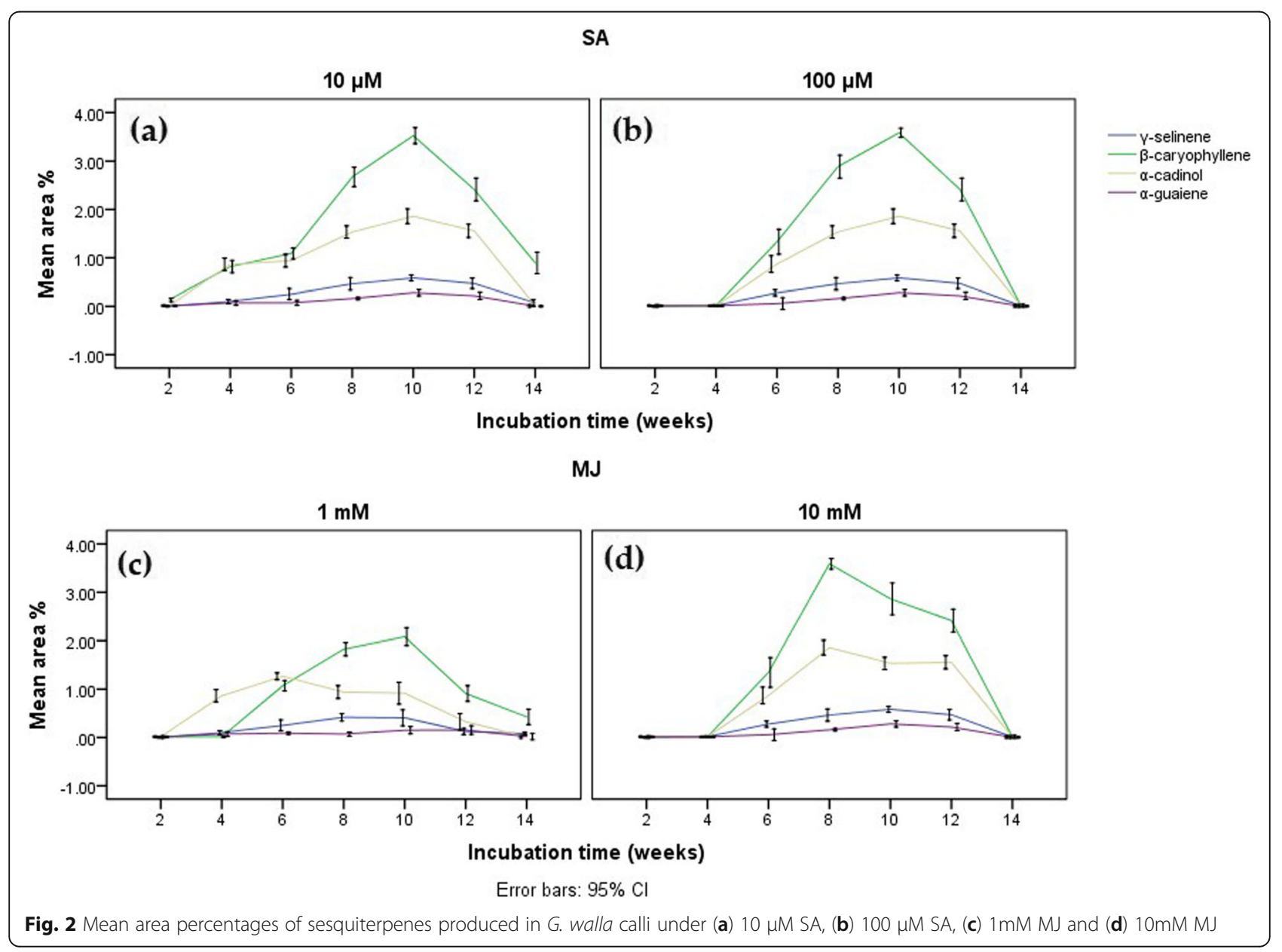


resultant supernatant was evaporated at room temperature to remove excess solvent and stored in $4{ }^{\circ} \mathrm{C}$ until chemicals analysis.

\section{Chemical analysis}

Chemical analyses were performed at the Herbal Division, Industrial Technology Institute (ITI), Malabe. Thin-layer chromatography (TLC) was performed using pre-coated Silica gel 60 GF254 plates and approximately $6 \mu \mathrm{l}$ of each sample was spotted on the TLC plate, airdried and placed in the chromatographic chamber previously saturated with the solvent system (25\% ethyl acetate and $75 \%$ hexane). Developed TLC plates were observed under UV $366 \mathrm{~nm}, 245 \mathrm{~nm}$ and after spraying with vanillin spray reagent followed by heating at $105{ }^{\circ} \mathrm{C}$ for $3-5 \mathrm{~min}$.

The GC-MS was run with a Thermo Scientific Trace 1300 (USA) fused with silica HP-5MS capillary column $(30 \mathrm{~m} \times 0.25 \mathrm{~mm} \times 0.25 \mu \mathrm{m})$. The oven temperature was programmed initially at $50{ }^{\circ} \mathrm{C}$ for $2 \mathrm{~min}$ following $200{ }^{\circ} \mathrm{C}$ for $1 \mathrm{~min}$ with a rate of $40{ }^{\circ} \mathrm{C} / \mathrm{min}$ and at $320^{\circ} \mathrm{C}$ for 15 min with a rate of $3{ }^{\circ} \mathrm{C} / \mathrm{min}$. The gas chromatogram was coupled to an ISQDD mass selective detector (Thermo Scientific, USA). The MS operating parameters were ionization voltage, $70 \mathrm{eV}$, and ion source temperature, $250{ }^{\circ} \mathrm{C}$. High-purity (over purity $99.99 \%$ ) helium was used as the carrier gas. Identification of compounds was based on comparisons of their mass spectra with those

Table 1 Effect of Chemical elicitors on Gyrinops walla calli

\begin{tabular}{|c|c|c|c|c|c|c|}
\hline \multirow{2}{*}{$\begin{array}{l}\text { Type of } \\
\text { elicitation }\end{array}$} & \multirow[t]{2}{*}{ Concentration } & \multirow{2}{*}{$\begin{array}{l}\text { Incubation } \\
\text { period } \\
\text { (weeks) }\end{array}$} & \multicolumn{4}{|c|}{ Area percentage of } \\
\hline & & & $\gamma$-Selinene & $\beta$-Aryophyllene & a-Cardinol & a-Guaiene \\
\hline Control & 0 & 0 & $0.00(0.005)^{g}$ & $0.13(0.01)^{i}$ & $0.01(0.005)^{9}$ & $0.01(0.005)^{f}$ \\
\hline Salicylic acid & $10 \mu \mathrm{M}$ & 2 & $0.00(0.005)^{g}$ & $0.13(0.01)^{i}$ & $0.01(0.005)^{\mathrm{g}}$ & $0.01(0.005)^{f}$ \\
\hline Salicylic acid & $10 \mu \mathrm{M}$ & 4 & $0.10(0.01)^{\mathrm{ef}}$ & $0.81(0.05)^{g h}$ & $0.86(0.05)^{e}$ & $0.07(0.02)^{d}$ \\
\hline Salicylic acid & $10 \mu \mathrm{M}$ & 6 & $0.25(0.04)^{d}$ & $1.09(0.04)^{g}$ & $0.94(0.05)^{\text {de }}$ & $0.07(0.02)^{d}$ \\
\hline Salicylic acid & $10 \mu \mathrm{M}$ & 8 & $0.46(0.05)^{b}$ & $2.67(0.08)^{b}$ & $1.53(0.05)^{b}$ & $0.16(0.01)^{c}$ \\
\hline Salicylic acid & $10 \mu \mathrm{M}$ & 10 & $0.58(0.02)^{a}$ & $3.52(0.06)^{a}$ & $1.86(0.06)^{\mathrm{a}}$ & $0.28(0.02)^{\mathrm{a}}$ \\
\hline Salicylic acid & $10 \mu \mathrm{M}$ & 12 & $0.47(0.04)^{b}$ & $2.41(0.09)^{c}$ & $1.55(0.05)^{b}$ & $0.21(0.03)^{b}$ \\
\hline Salicylic acid & $10 \mu \mathrm{M}$ & 14 & $0.07(0.02)^{\mathrm{fg}}$ & $0.89(0.09)^{g h}$ & $0.01(0.01)^{9}$ & $0.01(0.005)^{f}$ \\
\hline Salicylic acid & $100 \mu \mathrm{M}$ & 2 & $0.01(0.005)^{\mathrm{g}}$ & $0.01(0.001)^{i}$ & $0.01(0.003)^{9}$ & $0.01(0.005)^{f}$ \\
\hline Salicylic acid & $100 \mu \mathrm{M}$ & 4 & $0.01(0.005)^{9}$ & $0.01(0.005)^{i}$ & $0.01(0.005)^{9}$ & $0.01(0.003)^{f}$ \\
\hline Salicylic acid & $100 \mu \mathrm{M}$ & 6 & $0.27(0.02)^{d}$ & $1.33(0.10)^{f}$ & $0.87(0.07)^{\mathrm{e}}$ & $0.05(0.01)^{\mathrm{de}}$ \\
\hline Salicylic acid & $100 \mu \mathrm{M}$ & 8 & $0.46(0.05)^{b}$ & $2.88(0.09)^{\mathrm{b}}$ & $1.53(0.05)^{b}$ & $0.16(0.01)^{c}$ \\
\hline Salicylic acid & $100 \mu \mathrm{M}$ & 10 & $0.58(0.02)^{a}$ & $3.58(0.03)^{\mathrm{a}}$ & $1.86(0.06)^{\mathrm{a}}$ & $0.28(0.02)^{a}$ \\
\hline Salicylic acid & $100 \mu \mathrm{M}$ & 12 & $0.47(0.04)^{b}$ & $0.24(0.09)^{c}$ & $1.55(0.05)^{b}$ & $0.21(0.03)^{b}$ \\
\hline Salicylic acid & $100 \mu \mathrm{M}$ & 14 & $0.01(0.001)^{9}$ & $0.01(0.001)^{i}$ & $0.01(0.001)^{9}$ & $0.01(0.005)^{f}$ \\
\hline Methyl jasmonate & $1 \mathrm{mM}$ & 2 & $0.01(0.005)^{9}$ & $0.01(0.001)^{i}$ & $0.01(0.005)^{9}$ & $0.01(0.005)^{f}$ \\
\hline Methyl jasmonate & $1 \mathrm{mM}$ & 4 & $0.10(0.01)^{\mathrm{ef}}$ & $0.01(0.005)^{i}$ & $0.86(0.05)^{\mathrm{e}}$ & $0.07(0.02)^{d}$ \\
\hline Methyl jasmonate & $1 \mathrm{mM}$ & 6 & $0.25(0.04)^{d}$ & $1.07(0.04)^{9}$ & $1.26(0.02)^{c}$ & $0.09(0.01)^{d}$ \\
\hline Methyl jasmonate & $1 \mathrm{mM}$ & 8 & $0.41(0.03)^{b c}$ & $1.82(0.05)^{\mathrm{e}}$ & $0.94(0.05)^{\text {de }}$ & $0.07(0.01)^{d}$ \\
\hline Methyl jasmonate & $1 \mathrm{mM}$ & 10 & $0.40(0.06)^{c}$ & $2.08(0.07)^{d}$ & $0.91(0.09)^{d}$ & $0.15(0.03)^{c}$ \\
\hline Methyl jasmonate & $1 \mathrm{mM}$ & 12 & $0.12(0.02)^{\mathrm{e}}$ & $0.91(0.06)^{g h}$ & $0.32(0.06)^{f}$ & $0.15(0.03)^{c}$ \\
\hline Methyl jasmonate & $1 \mathrm{mM}$ & 14 & $0.08(0.01)^{\mathrm{fg}}$ & $0.43(0.06)^{h}$ & $0.01(0.001)^{9}$ & $0.02(0.02)^{\mathrm{ef}}$ \\
\hline Methyl jasmonate & $10 \mathrm{mM}$ & 2 & $0.01(0.005)^{9}$ & $0.01(0.01)^{i}$ & $0.01(0.005)^{\mathrm{g}}$ & $0.01(0.005)^{f}$ \\
\hline Methyl jasmonate & $10 \mathrm{mM}$ & 4 & $0.01(0.005)^{9}$ & $0.01(0.005)^{i}$ & $0.01(0.003)^{9}$ & $0.01(0.004)^{f}$ \\
\hline Methyl jasmonate & $10 \mathrm{mM}$ & 6 & $0.27(0.02)^{b}$ & $1.34(0.12)^{f}$ & $0.87(0.07)^{\mathrm{e}}$ & $0.05(0.04)^{\mathrm{de}}$ \\
\hline Methyl jasmonate & $10 \mathrm{mM}$ & 8 & $0.46(0.05)^{b}$ & $3.59(0.04)^{a}$ & $1.86(0.06)^{\mathrm{a}}$ & $0.16(0.01)^{c}$ \\
\hline Methyl jasmonate & $10 \mathrm{mM}$ & 10 & $0.50(0.02)^{a}$ & $2.86(0.13)^{b}$ & $1.53(0.05)^{b}$ & $0.28(0.02)^{a}$ \\
\hline Methyl jasmonate & $10 \mathrm{mM}$ & 12 & $0.47(0.04)^{b}$ & $2.41(0.09)^{c}$ & $1.55(0.05)^{b}$ & $0.21(0.03)^{b}$ \\
\hline Methyl jasmonate & $10 \mathrm{mM}$ & 14 & $0.01(0.01)^{9}$ & $0.01(0.01)^{i}$ & $0.01(0.01)^{9}$ & $0.01(0.005)^{f}$ \\
\hline
\end{tabular}


recorded in the National Institute of Standards and Technology database (NIST, Version 2.09, MD, USA).

\section{Data analysis}

The descriptive statistics such as mean and standard deviation (SD) were calculated for the data obtained. Further, the relationship between the incubation time and area percentages of sesquiterpenes were graphically presented along with the trends. The inferential statistics such ANOVA and Tukey's honest test were performed to compare the means. All statistical analyses were performed using SAS (Ver. 9) (2008).

\section{Results}

Effectiveness of the production of sesquiterpenes in calli and cell suspensions subjected to different stress stimuli were initially assessed via visual observation on callus/cell suspension colour, sensory evaluation by sniffing before harvesting and TLC profiles observed under UV $366 \mathrm{~nm}$, which had similar profiles to that of hexane extracts $G$. walla wood after harvesting. The results were used to determine the stress conditions to be further analysed via GC-MS to assess the amount of sesquiterpenes. Considering the relative abundance of sesquiterpenes detected via GC-MS, the relative percentage of four (04) prominent sesquiterpenes, namely $\gamma$-selinene, $\beta$-caryophyllene, $\alpha$ cadinol and $\alpha$-guaiene, were used to assess the productivity of each elicitation method and their conditions. Silane and siloxane compounds were neglected in obtained chromatograms.

Chemical elicitation of $G$. walla callus and cell suspension The changes in callus were noted during the stress under varying concentrations of chemical elicitors at different time intervals. In the control, apparent changes of the callus were not observed. On chemical elicitation with $10 \mu \mathrm{M}$ SA and $100 \mu \mathrm{M}$ SA, spots on TLC appeared on the 8th and 6th week, respectively. Calli turned to brown after the 10th week and 12th week and spots were not observed on the TLC. Chemical elicitation with $\mathrm{MJ}$ induced browning in most of the experimented calli and TLC spots were obtained after the 8th week except for MJ $100 \mathrm{mM}$. During the chemical elicitation of G. walla calli, odour was not sensed in both elicitors.

Three spots with $R_{f}$ values of $0.51,0.32$ and 0.21 were observed in TLC profiles of chemically elicited G. walla calli. These spots of prominent light blue and maroon in colour were observed in all the TLC profiles of chemically elicited G. walla calli (Fig. 1).

Results obtained from GC-MS chromatograms of the elicited calli resulted in curve-shaped graphs, indicating the response of calli in the occurrence of sesquiterpenes during the incubation period. The maximum area percentage of desired sesquiterpenes was observed for calli, which were elicited with SA and MJ, on the 8th and 10th week (Fig. 2). Comparatively, the maximum area percentage of sesquiterpenes under the treatment of SA produced sesquiterpenes in $10 \mu \mathrm{M} \mathrm{SA}$ which were equal to that in $100 \mu \mathrm{M} \mathrm{SA}$ (Table 1). On the other hand, the maximum area percentage of sesquiterpenes were obtained in $10 \mathrm{mM}$ of $\mathrm{MJ}$ with $3.59 \%$ of $\beta$ caryophyllene and $1.86 \%$ of $\alpha$-cadinol on the 8 th week, and $0.58 \%$ of $\gamma$-selinene and $0.28 \%$ of $\alpha$-guaiene on the 10th week (Table 1). In comparison, the area percentage of $\beta$-caryophyllene is higher in all elicitor conditions while $\gamma$-selinene and $\alpha$-guaiene are the lowest (Fig. 2). In general, the effect of SA and MJ on the area percentage of sesquiterpenes showed a tendency of producing similar results. Cell viability with the TTC reduction test indicated that elicited calli

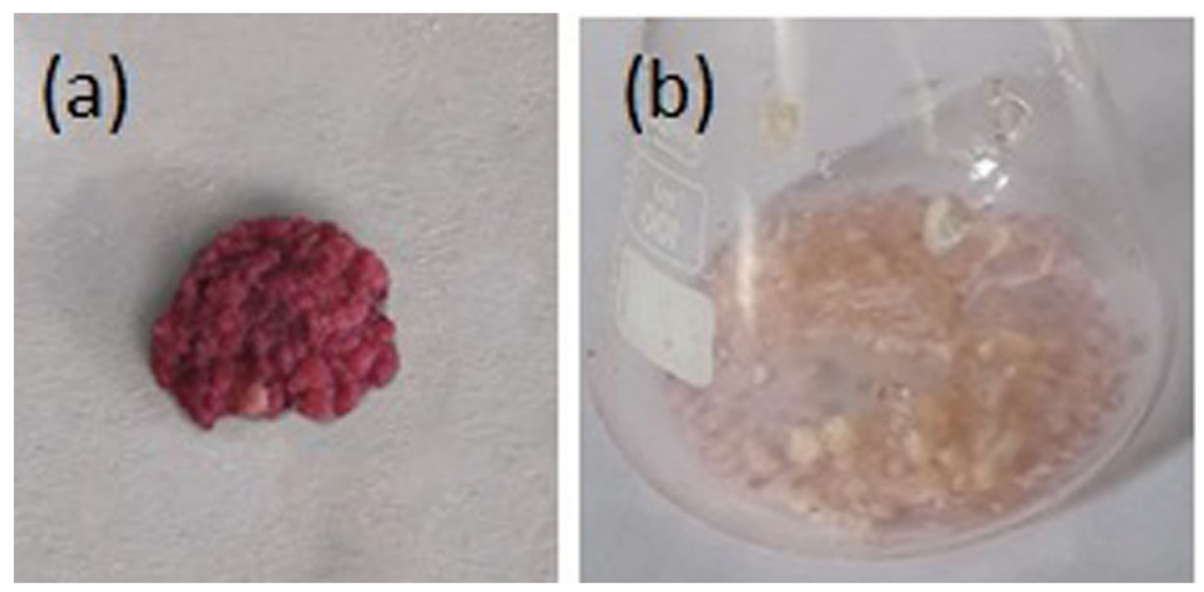

Fig. 3 Cell viability of G. walla (a) calli and (b) cell suspension after the TTC reduction test 
were viable only up to the 8 th or 10 th week during the incubation period (Fig. 3a).

The cell suspension of G. walla treated with different chemical stimuli ( $\mathrm{MJ}$ and SA) resulted in lesser browning and TLC spots appeared only for SA 0.5 $\mu \mathrm{M}$ and MJ $0.1 \mathrm{mM}$ after $4 \mathrm{~h}$ and onwards. However, on the 72nd hour, TLC spots were not observed for both chemical elicitors. Most significantly, a slight aroma was sensed when G. walla cell suspensions were incubated with $0.1 \mathrm{mM} \mathrm{MJ}$ on the 6th hour. Cell viability with the TTC reduction test indicated that elicited cell suspensions were viable only up to the 6th or 12th hour during the incubation period and majority of the cell suspensions were not viable on the 72nd hour (Fig. 3b).

The TLC profiles of G. walla cell suspension indicated similar observations to that of G. walla calli with prominent light blue and maroon spots (Fig. 4).

Similar patterns were observed in cell suspensions under SA and MJ with the highest area percentage of sesquiterpenes on the 6th and 12th hour (Fig. 5). A higher area percentage of $\gamma$-selinene $(0.44 \%)$ and $\alpha$ -

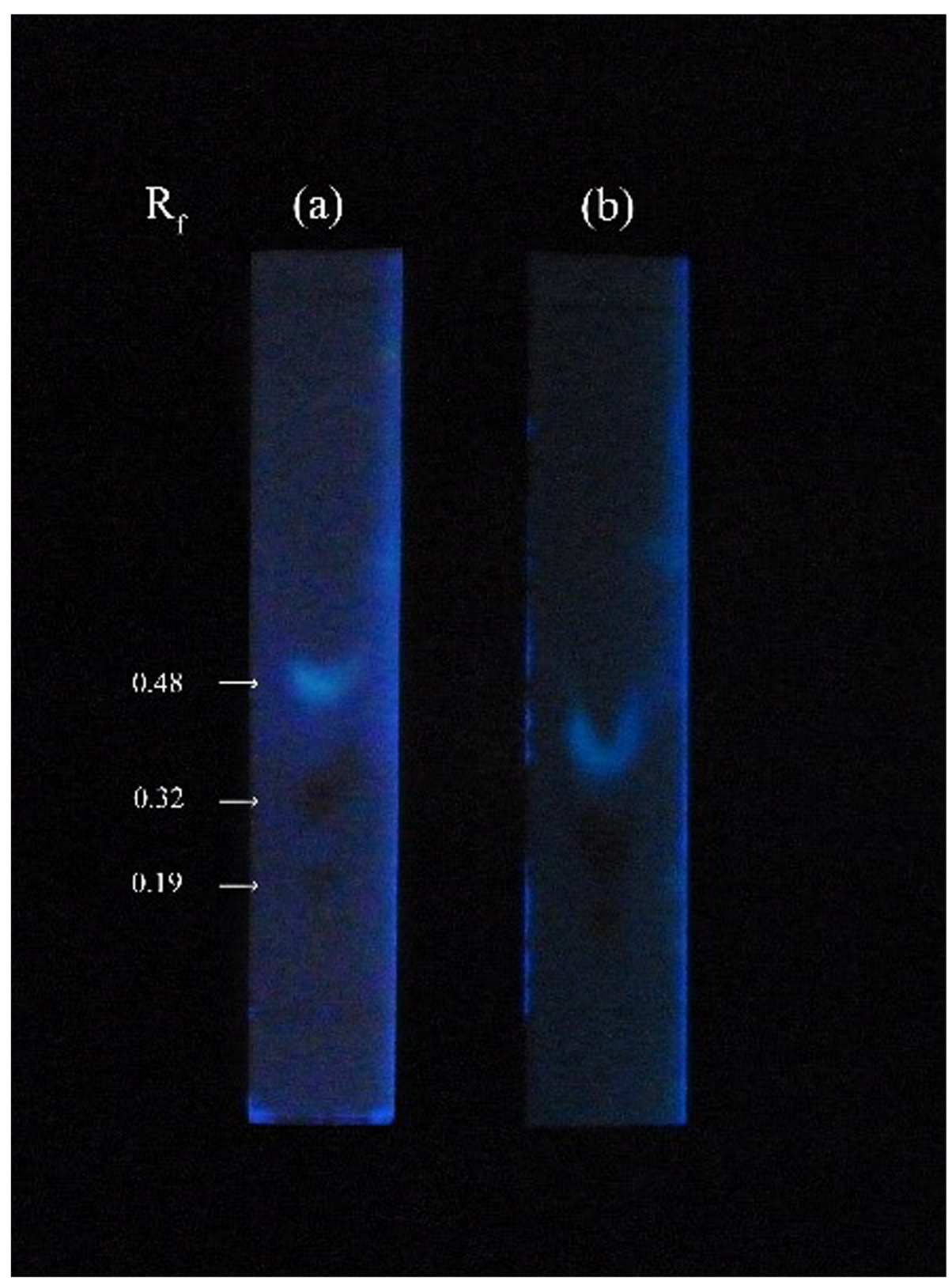

Fig. 4 TLC profiles resulting from the chemically elicited cell suspension (a) SA $0.5 \mu \mathrm{M}$ and (b) MJ $0.1 \mathrm{mM}$ on the 6th hour 
Table 2 Effect of Chemical elicitors on Gyrinops walla cell suspension

\begin{tabular}{|c|c|c|c|c|c|c|}
\hline \multirow{2}{*}{$\begin{array}{l}\text { Type of } \\
\text { elicitation }\end{array}$} & \multirow[t]{2}{*}{ Concentration } & \multirow{2}{*}{$\begin{array}{l}\text { Incubation } \\
\text { period } \\
\text { (hours) }\end{array}$} & \multicolumn{4}{|c|}{ Area percentage of } \\
\hline & & & $\gamma$-Selinene & $\beta$-Caryophyllene & a-Cardinol & a-Guaiene \\
\hline Control & 0 & 0 & $0.01(0.005)^{e}$ & $0.01(0.01)^{\mathrm{e}}$ & $0.01(0.005)^{f}$ & $0.01(0.005)^{d}$ \\
\hline Salicylic acid & $0.5 \mu \mathrm{M}$ & 0.5 & $0.01(0.005)^{\mathrm{e}}$ & $0.01(0.01)^{\mathrm{e}}$ & $0.01(0.005)^{f}$ & $0.01(0.005)^{d}$ \\
\hline Salicylic acid & $0.5 \mu \mathrm{M}$ & 2 & $0.08(0.005)^{\text {de }}$ & $0.01(0.005)^{e}$ & $0.13(0.01)^{f}$ & $0.06(0.02)^{c}$ \\
\hline Salicylic acid & $0.5 \mu \mathrm{M}$ & 4 & $0.13(0.03)^{c d}$ & $0.05(0.01)^{\mathrm{e}}$ & $0.94(0.05)^{\mathrm{cd}}$ & $0.07(0.02)^{c}$ \\
\hline Salicylic acid & $0.5 \mu \mathrm{M}$ & 6 & $0.28(0.03)^{b}$ & $2.07(0.10)^{b}$ & $1.02(0.06)^{c}$ & $0.16(0.01)^{b}$ \\
\hline Salicylic acid & $0.5 \mu \mathrm{M}$ & 12 & $0.44(0.02)^{a}$ & $1.97(0.02)^{\mathrm{a}}$ & $1.53(0.05)^{\mathrm{a}}$ & $0.21(0.03)^{\mathrm{a}}$ \\
\hline Salicylic acid & $0.5 \mu \mathrm{M}$ & 24 & $0.14(0.04)^{c}$ & $0.41(0.07)^{\mathrm{cd}}$ & $0.14(0.03)^{f}$ & $0.12(0.02)^{b c}$ \\
\hline Salicylic acid & $0.5 \mu \mathrm{M}$ & 72 & $0.05(0.04)^{d}$ & $0.20(0.05)^{\mathrm{cd}}$ & $0.02(0.002)^{f}$ & $0.02(0.002)^{d}$ \\
\hline Methyl jasmonate & $0.1 \mathrm{mM}$ & 0.5 & $0.01(0.005)^{\mathrm{e}}$ & $0.01(0.001)^{\mathrm{e}}$ & $0.01(0.005)^{f}$ & $0.01(0.005)^{d}$ \\
\hline Methyl jasmonate & $0.1 \mathrm{mM}$ & 2 & $0.09(0.001)^{\mathrm{cd}}$ & $0.01(0.005)^{\mathrm{e}}$ & $0.35(0.10)^{\text {de }}$ & $0.07(0.002)^{c}$ \\
\hline Methyl jasmonate & $0.1 \mathrm{mM}$ & 4 & $0.18(0.02)^{c}$ & $0.90(0.07)^{d}$ & $0.71(0.04)^{e}$ & $0.04(0.005)^{\mathrm{cc}}$ \\
\hline Methyl jasmonate & $0.1 \mathrm{mM}$ & 6 & $0.37(0.02)^{a}$ & $2.07(0.08)^{b}$ & $0.91(0.08)^{\mathrm{cd}}$ & $0.15(0.03)^{b}$ \\
\hline Methyl jasmonate & $0.1 \mathrm{mM}$ & 12 & $0.25(0.04)^{b}$ & $1.07(0.04)^{c}$ & $1.26(0.02)^{b}$ & $0.15(0.03)^{b}$ \\
\hline Methyl jasmonate & $0.1 \mathrm{mM}$ & 24 & $0.09(0.005)^{\mathrm{cd}}$ & $0.99(0.30)^{d}$ & $0.86(0.01)^{\mathrm{e}}$ & $0.25(0.02)^{\mathrm{a}}$ \\
\hline Methyl jasmonate & $0.1 \mathrm{mM}$ & 72 & $0.08(0.004)^{\text {de }}$ & $0.04(0.01)^{\mathrm{e}}$ & $0.01(0.003)^{f}$ & $0.04(0.01)^{d}$ \\
\hline
\end{tabular}

The mean values are followed by standard deviation within parentheses. The same letter along the columns indicates no statistically significant difference at $\mathrm{p}$ $\leq 0.05$

cadinol (1.53\%) was reported for SA while MJ induced a higher production of $\alpha$-guaiene $(0.25 \%)$ and $\beta$ caryophyllene (2.07\%) (Table 2). Earlier production of $\alpha$ cadinol and later production $\beta$-caryophyllene were prominent while cell suspensions were elicited with SA and MJ (Fig. 5). This pattern of chemical appearance was similar to G. walla calli with maximum area percentages of $\beta$-caryophyllene and $\alpha$-cadinol, and minimum area percentages of $\gamma$-selinene and $\alpha$-guaiene during the incubation period for both elicitors.

For G. walla calli and cell suspension under the treatment of chemical elicitation, two distinguishable patterns of occurrence of sesquiterpenes were observed (Fig. 6). The area percentage of $\beta$-caryophyllene and $\alpha$ cadinol were higher in both culture conditions while $\gamma$ - selinene and $\alpha$-guaiene were lower. Meanwhile, the sesquiterpenes, $\gamma$-selinene and $\alpha$-guaiene in calli and cell suspension behave similarly; $\beta$-caryophyllene and $\alpha$ cadinol act conversely in two culture conditions. Comparatively, earlier production of $\beta$-caryophyllene and $\alpha$ cadinol was observed in G. walla calli and cell suspension, respectively.

Biological elicitation of $G$. walla callus and cell suspension Six biological elicitors performed differently on each stress condition changing the physical characters of $G$. walla calli. Comparatively, the effect of fungal strains Fusariym oxysporum, Aspergillus niger and Penicillium commune had little or no effect on $G$. walla calli except

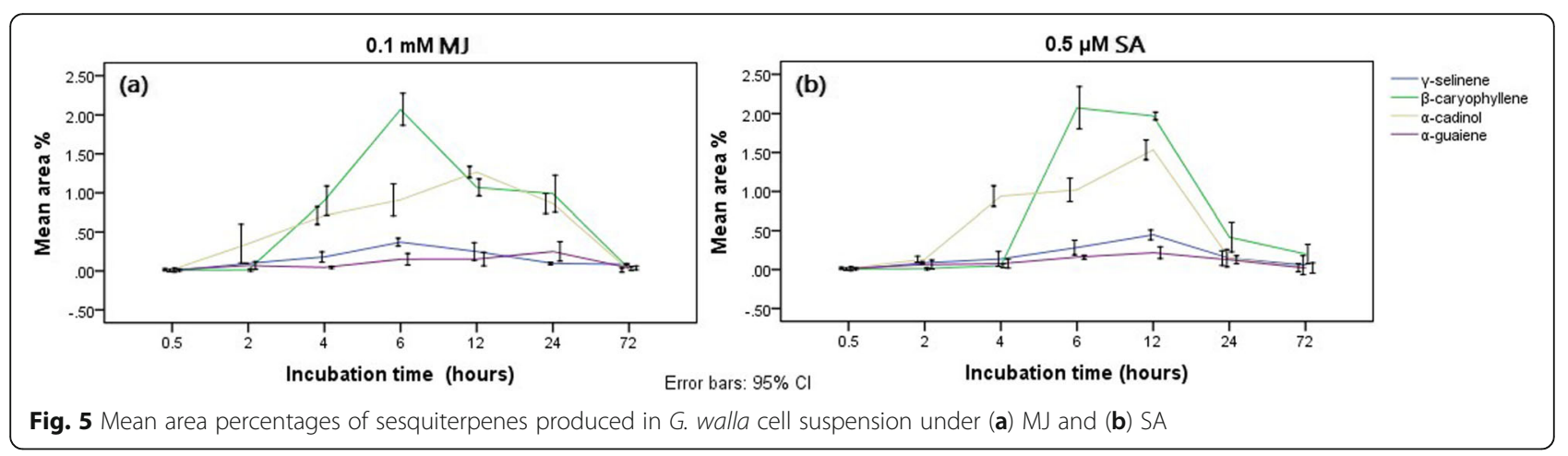



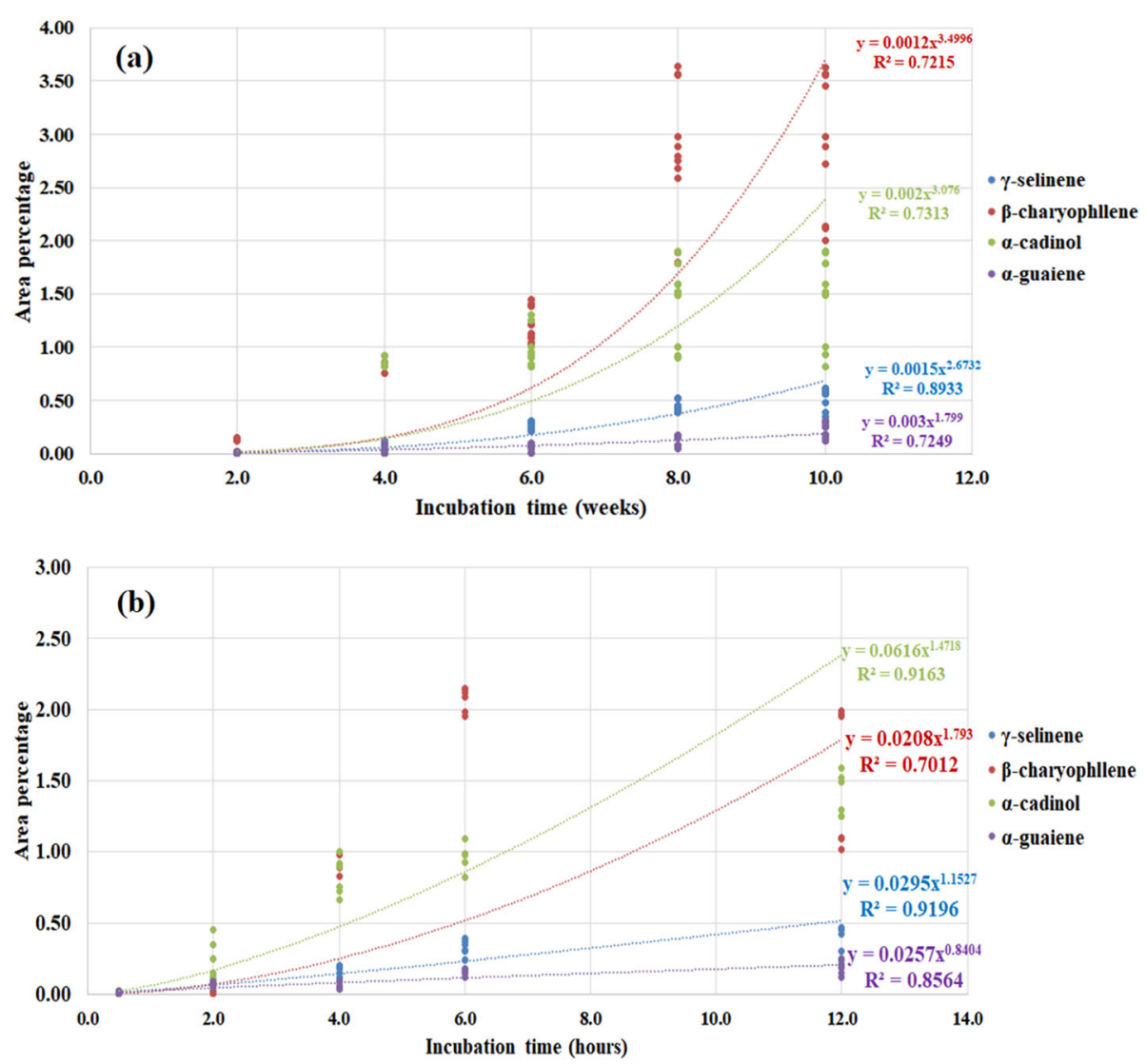

Fig. 6 Trends of area percentages of chemically elicited (a) G. walla calli and (b) cell suspension. The graphs present the data up to the maximum area percentage of sesquiterpenes

for browning. In contrast, fungal strains Phaeocremonium parasitica, Trichoderma viride and Lasidiplodia theobromae produced spots on TLC plates on the 4th week onwards and aroma was sensed in some of the elicited conditions. Extensive browning was observed for the elicitation caused by Lasidiplodia theobromae that intensified at the end of the incubation period (Fig. 7). Cell viability with the TTC reduction test indicated that elicited calli were viable only up to the 8th or 10th week during the incubation period.
TLC profiles of extracts of elicited calli indicted vivid spot patterns with light to dark, blue and yellow in colour with few spots in maroon colour with $R_{\mathrm{f}}$ values of $0.86,0.82,0.76,0.59,0.44,0.34,0.25$ and 0.14 all three fungal strains: Phaeocremonium parasitica, Trichoderma viride and Lasidiplodia theobromae (Fig. 8).

The results obtained from the GC-MS chromatogram of the elicited G. walla calli revealing comparatively a maximum area percentage of sesquiterpenes for three fungal strains are presented graphically (Figs. 9 and 10). The calli elicited by $P$. parasitica indicated a higher area percentage
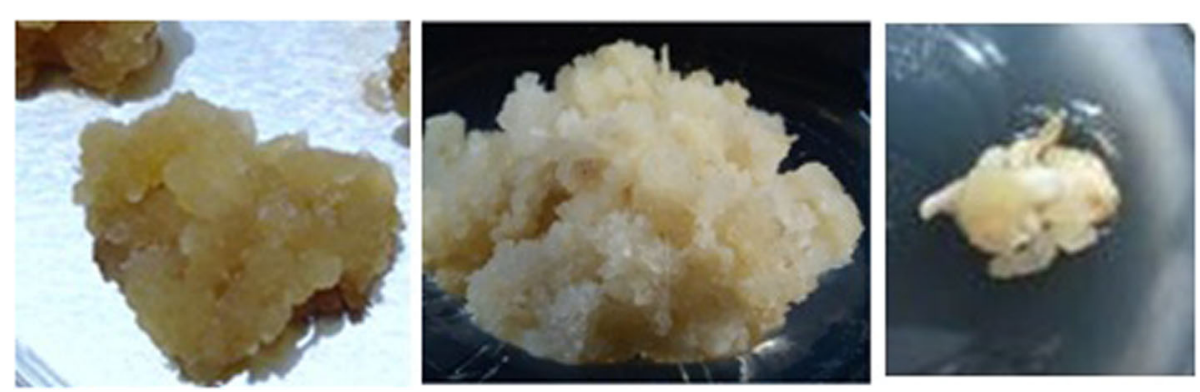

Fig. 7 Browning of the calli on elicitation with L. theobromae 


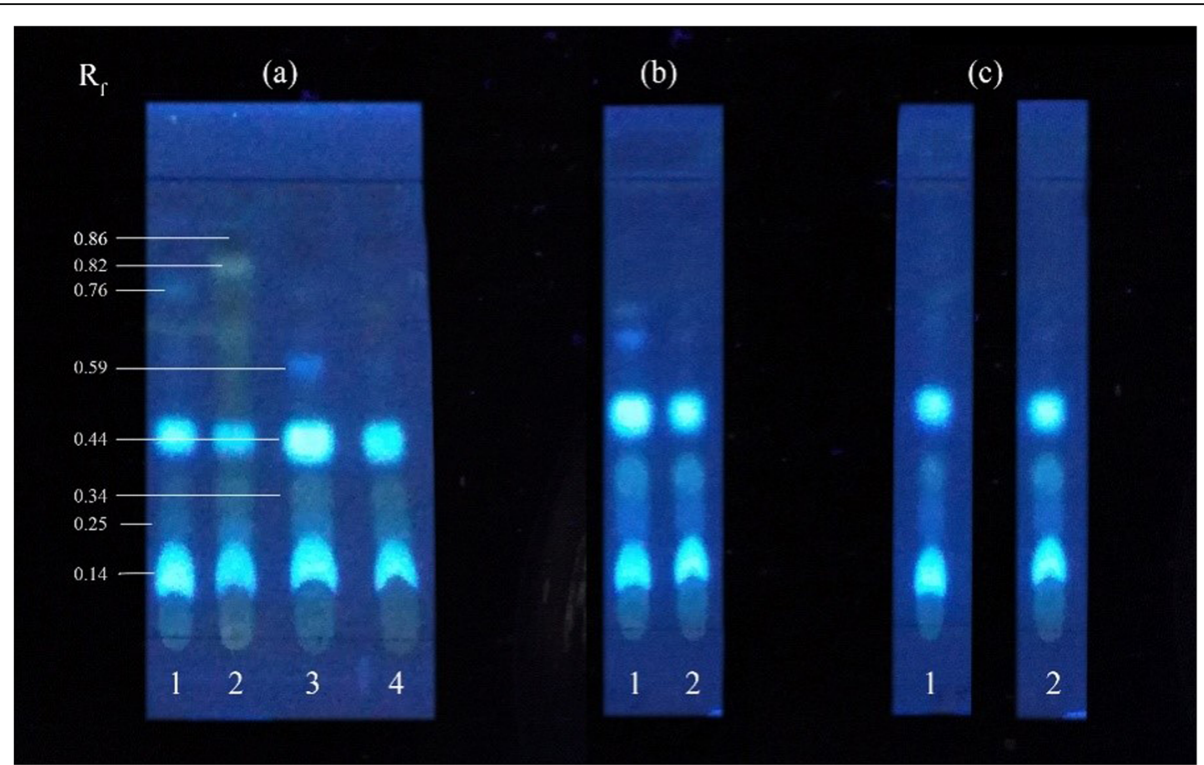

Fig. 8 TLC profiles of biologically elicited G. walla calli (a) P. parasitica (1) $25 \mathrm{mg} / \mathrm{L}$, (2) $50 \mathrm{mg} / \mathrm{L}, 75 \mathrm{mg} / \mathrm{L}, 100 \mathrm{mg} / \mathrm{L}$; (b) T. viride (1) $75 \mathrm{mg} / \mathrm{L}$, (2) $100 \mathrm{mg} / \mathrm{L}$; and (c) L. theobromae (1) $75 \mathrm{mg} / \mathrm{L}$, (2) $100 \mathrm{mg} / \mathrm{L}$ on the 10 th week

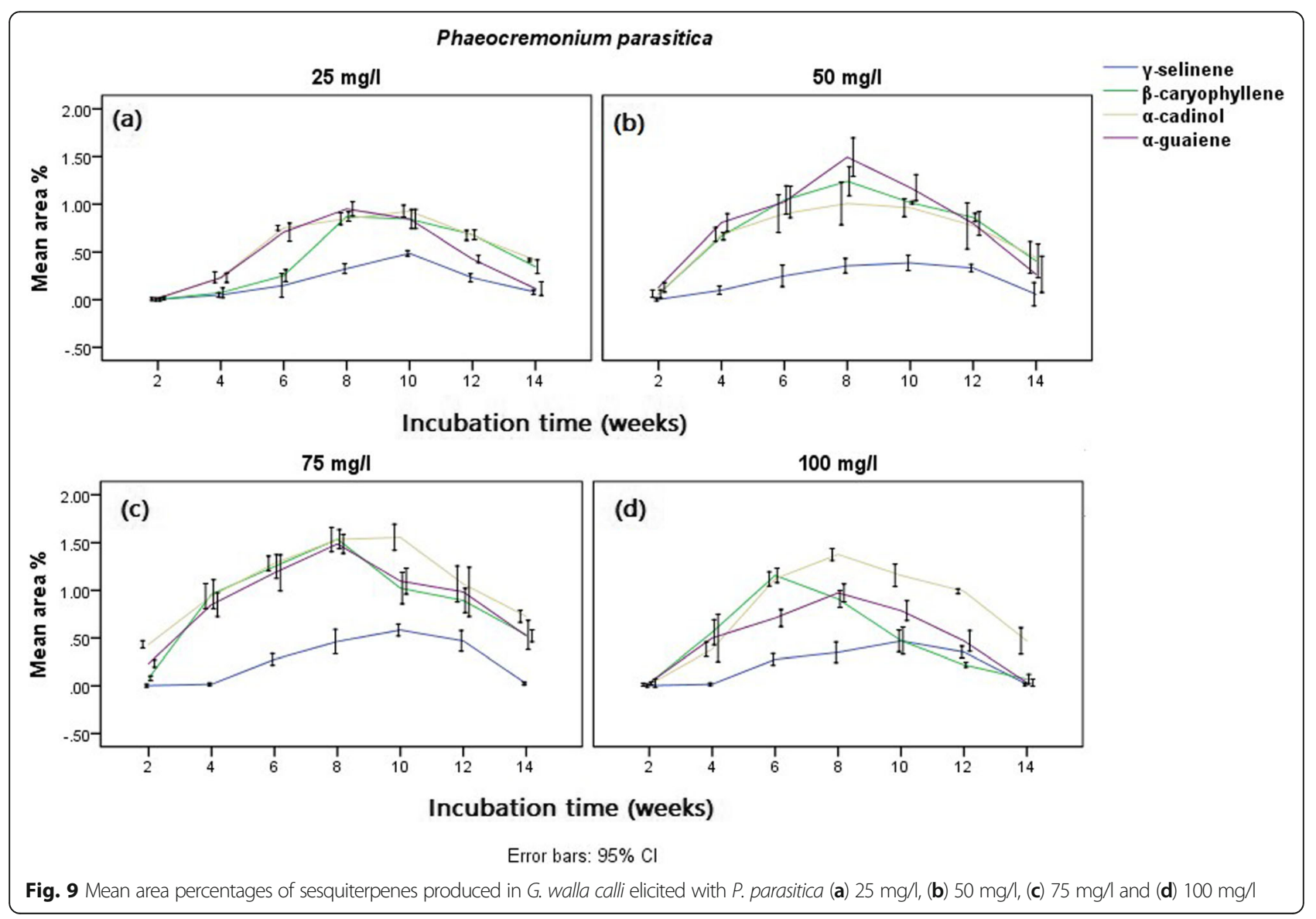




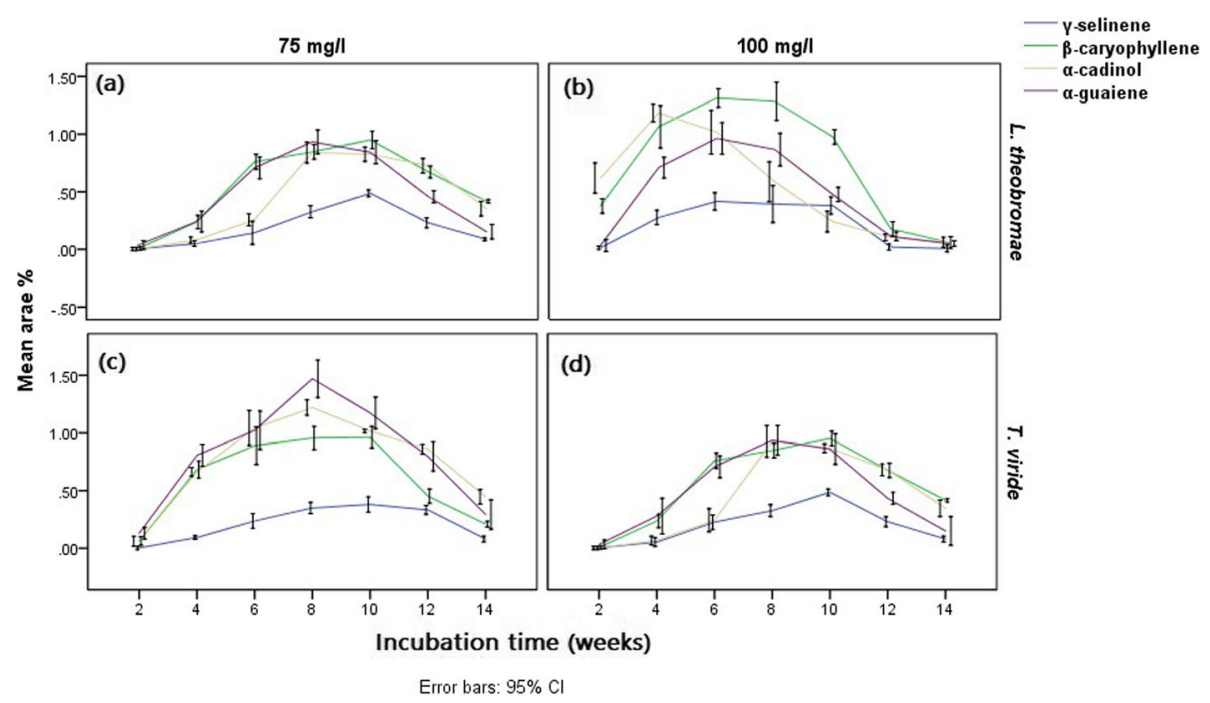

Fig. 10 Mean area percentages of sesquiterpenes produced in G. walla calli elicited with (a) 75 mg/l, (b) 100 mg/l L. theobromae and (c) 75 mg/l, (d) $100 \mathrm{mg} / \mathrm{l} \mathrm{T}$. viride

of sesquiterpenes in the 6th, 8th and 10th week of incubation for tested concentrations (Fig. 9). Among the concentrations, the highest area percentage of sesquiterpenes were observed in calli treated with $75 \mathrm{mg} / \mathrm{l}$ and kept for 8-10 weeks of incubation ( $\gamma$-selinene $-0.58 \%, \beta$ caryophyllene $-1.53 \%$ and $\alpha$-cadinol $-1.55 \%$ ) (Table 3 ). Similarly, the concentrations $75 \mathrm{mg} / \mathrm{L}$ and $100 \mathrm{mg} / \mathrm{L}$ of Trichoderma viride were observed to be effective in the biological elicitation of G. walla calli, producing the highest sesquiterpene area percentages on the 8th and 10th week (Fig. $10 \mathrm{c}$ and d). Comparatively, a higher area percentage of sesquiterpenes was yielded for calli under 75 $\mathrm{mg} / \mathrm{L}$ T.viride ( $\beta$-caryophyllene $-0.96 \%, \alpha$-cadinol $1.22 \%$ and $\alpha$-guaiene $-1.47 \%)$. For calli under the concentration of $75 \mathrm{mg} / \mathrm{L}$, Lasidiplodia theobromae showed a behavioural pattern similar to that of the other two biological-elicitors, producing a higher area percentage of sesquiterpenes in the 8th and 10th week (Fig. $10 \mathrm{a}$ and b). On the contrary, higher area percentages of desired sesquiterpenes were obtained from the 4 th week ( $\alpha$-cadinol) and 6th week ( $\beta$-caryophyllene, $\alpha$-guaiene and $\gamma$-selinene) under the treatment of $100 \mathrm{mg} / \mathrm{L}$ L. theobromae (Table 3). Out of the three positive fungal stains and their concentrations, calli incubated under $75 \mathrm{mg} / \mathrm{L} P$. parasitica for 8-10 weeks yielded a higher area percentage of three sesquiterpenes comparatively. The area percentages of sesquiterpenes differed from that of chemical and electrostimulation. Characteristically, higher area percentages of $\alpha$-cadinol, $\beta$-caryophyllene and $\alpha$-guaiene were observed for three fungal strains which gradually reduced at the end of the incubation period (Figs. 9 and 10).

PP, Phaeocremonium parasitica; TV, Trichoderma viride; and LT, Lasidiplodia theobromae. The mean values are followed by standard deviation within parentheses. The same letter along the columns indicates no statistically significant difference at $\mathrm{p} \leq 0.05$

A rapid browning of cell suspension cultures with Phaeocremonium parasitica, Trichoderma viride and Lasidiplodia theobromae fungal strains was observed within $24 \mathrm{~h}$ subsequently to the biological elicitation. However, such browning was not observed in the control and the fungal strains Fusariym oxysporum, Aspergillus niger and Penicillium commune. Smell was detected in higher concentrations of biological elicitors $(8 \mathrm{mg} / \mathrm{L}$ and $10 \mathrm{mg} / \mathrm{L})$ of Phaeocremonium parasitica and Lasidiplodia theobromae after $6 \mathrm{~h}$ of incubation and Trichoderma viride indicated no sign of change in the cell suspension. Cell viability with TTC reduction test indicated that elicited cell suspensions were viable only upto 6th or 12th hour during the incubation period and majority the cell suspensions were not viable in the 72nd hour. However, the TTC reduction test on Trichoderma viride indicated that cell suspensions in all the incubation periods were not viable.

TLC profiles of G. walla cell suspension under biological elicitation indicated a similarity to that of chemical elicitation with prominent light blue and maroon spots which, however, differed from spots observed in $G$. walla calli under biological elicitation (Fig. 11).

Graphical presentation of biological elicitation of $G$. walla cell suspensions are shown in Fig. 12. According to the figure, $6 \mathrm{mg} / \mathrm{L}, 8 \mathrm{mg} / \mathrm{L}$ and $10 \mathrm{mg} / \mathrm{L}$ of Phaeocremonium parasitica (Fig. $12 \mathrm{a}, \mathrm{b}$ and c) and $8 \mathrm{mg} / \mathrm{L}$ and $10 \mathrm{mg} / \mathrm{L}$ of Lasidiplodia theobromae (Fig. $12 \mathrm{~d}$ and e) on the 6th and 12th hour of incubation periods were more effective in the occurrence of sesquiterpenes. Comparatively, $8 \mathrm{mg} / \mathrm{L}$ and $10 \mathrm{mg} / \mathrm{L}$ Phaeocremonium parasitica 
Table 3 Effect of biological elicitors on Gyrinops walla calli

\begin{tabular}{|c|c|c|c|c|c|c|}
\hline \multirow{2}{*}{$\begin{array}{l}\text { Type of } \\
\text { elicitation }\end{array}$} & \multirow{2}{*}{$\begin{array}{l}\text { Concentration } \\
\text { (mg/L) }\end{array}$} & \multirow{2}{*}{$\begin{array}{l}\text { Incubation } \\
\text { period } \\
\text { (weeks) }\end{array}$} & \multicolumn{4}{|c|}{ Area percentage of } \\
\hline & & & Y-Selinene & $\beta$-Caryophyllene & a-Cardinol & a-Guaiene \\
\hline Control & 0 & 0 & $0.01(0.005)^{n}$ & $0.01(0.002)^{z}$ & $0.01(0.006)^{x y}$ & $0.01(0.004)^{\mathrm{op}}$ \\
\hline PP & 25 & 2 & $0.01(0.005)^{\mathrm{n}}$ & $0.01(0.002)^{z}$ & $0.01(0.006)^{x y}$ & $0.01(0.004)^{\mathrm{oP}}$ \\
\hline PP & 25 & 4 & $0.05(0.002)^{\mathrm{mn}}$ & $0.07(0.02)^{z}$ & $0.23(0.02)^{\mathrm{wv}}$ & $0.23(0.02)^{n}$ \\
\hline PP & 25 & 6 & $0.15(0.05)^{j \mathrm{k}}$ & $0.25(0.02)^{x w}$ & $0.75(0.01)^{o n p}$ & $0.70(0.03)^{\mathrm{ij}}$ \\
\hline PP & 25 & 8 & $0.32(0.02)^{g \text { fh }}$ & $0.87(0.02)^{j \text { jimk }}$ & $0.84(0.02)^{\text {oqp }}$ & $0.95(0.03)^{\mathrm{feg}}$ \\
\hline PP & 25 & 10 & $0.48(0.01)^{\mathrm{a}}$ & $0.84(0.04)^{\text {lonm }}$ & $0.92(0.02)^{j \mid k i}$ & $0.84(0.04)^{\mathrm{fhg}}$ \\
\hline PP & 25 & 12 & $0.23(0.01)^{\mathrm{ji}}$ & $0.68(0.02)^{\mathrm{pq}}$ & $0.67(0.05)^{r s q p}$ & $0.42(0.01)^{\mathrm{m}}$ \\
\hline PP & 25 & 14 & $0.08(0.01)^{\mathrm{mn}}$ & $0.34(0.02)^{w}$ & $0.41(0.005)^{\mathrm{u}}$ & $0.11(0.02)^{\circ}$ \\
\hline PP & 50 & 2 & $0.01(0.0005)^{n}$ & $0.06(0.01)^{z}$ & $0.06(0.01)^{x y}$ & $0.13(0.02)^{\circ}$ \\
\hline PP & 50 & 4 & $0.10(0.001)^{\prime}$ & $0.66(0.01)^{r a}$ & $0.68(0.02)^{r s q}$ & $0.80(0.03)^{\text {ih }}$ \\
\hline PP & 50 & 6 & $0.25(0.04)^{\mathrm{ji}}$ & $1.04(0.06)^{\text {fheg }}$ & $0.90(0.08)^{\mathrm{j} \mathrm{jkm}}$ & $1.02(0.06)^{\mathrm{e}}$ \\
\hline PP & 50 & 8 & $0.35(0.03)^{\text {efg }}$ & $1.24(0.06)^{\mathrm{cd}}$ & $1.00(0.09)^{g h i}$ & $1.49(0.08)^{c}$ \\
\hline PP & 50 & 10 & $0.38(0.03)^{\mathrm{ef}}$ & $1.01(0.005)^{\text {fhg }}$ & $0.96(0.03)^{\mathrm{jhi}}$ & $1.17(0.05)^{d}$ \\
\hline PP & 50 & 12 & $0.33(0.01)^{\text {gfh }}$ & $0.86(0.01)^{\mathrm{Inmk}}$ & $0.77(0.09)^{\mathrm{onp}}$ & $0.79(0.05)^{\mathrm{ij}}$ \\
\hline PP & 50 & 14 & $0.05(0.004)^{\mathrm{mn}}$ & $0.40(0.07)^{\mathrm{w}}$ & $0.44(0.06)^{\mathrm{ut}}$ & $0.26(0.07)^{n}$ \\
\hline PP & 75 & 2 & $0.01(0.005)^{n}$ & $0.08(0.01)^{z}$ & $0.43(0.01)^{\mathrm{ut}}$ & $0.23(0.01)^{\mathrm{n}}$ \\
\hline PP & 75 & 4 & $0.01(0.005)^{n}$ & $0.96(0.06)^{\text {jfhigk }}$ & $0.94(0.05)^{j \mathrm{ki}}$ & $0.85(0.05)^{\text {fhg }}$ \\
\hline PP & 75 & 6 & $0.27(0.02)^{\text {ih }}$ & $1.25(0.05)^{c}$ & $1.28(0.03)^{\mathrm{ab}}$ & $1.18(0.07)^{d}$ \\
\hline PP & 75 & 8 & $0.46(0.05)^{\mathrm{bcd}}$ & $1.53(0.04)^{\mathrm{a}}$ & $1.53(0.05)^{c}$ & $1.48(0.04)^{\mathrm{a}}$ \\
\hline PP & 75 & 10 & $0.58(0.02)^{a}$ & $1.02(0.06)^{\mathrm{feg}}$ & $1.55(0.05)^{\mathrm{a}}$ & $1.09(0.05)^{b}$ \\
\hline PP & 75 & 12 & $0.47(0.04)^{b c}$ & $0.89(0.05)^{\mathrm{ponm}}$ & $1.06(0.07)^{g f}$ & $0.98(0.10)^{\mathrm{ef}}$ \\
\hline PP & 75 & 14 & $0.02(0.005)^{n}$ & $0.53(0.06)^{\mathrm{st}}$ & $0.72(0.02)^{\text {rqp }}$ & $0.52(0.02)^{\mathrm{ml}}$ \\
\hline PP & 100 & 2 & $0.01(0.005)^{\mathrm{n}}$ & $0.03(0.005)^{z}$ & $0.01(0.005)^{x y}$ & $0.02(0.01)^{\mathrm{op}}$ \\
\hline PP & 100 & 4 & $0.01(0.005)^{\mathrm{n}}$ & $0.56(0.05)^{\mathrm{sr}}$ & $0.38(0.03)^{\vee}$ & $0.50(0.10)^{\mathrm{ml}}$ \\
\hline PP & 100 & 6 & $0.27(0.02)^{\mathrm{gih}}$ & $1.15(0.03)^{\mathrm{ed}}$ & $1.12(0.03)^{\mathrm{fe}}$ & $0.71(0.03)^{i j}$ \\
\hline PP & 100 & 8 & $0.35(0.04)^{\mathrm{efg}}$ & $0.91(0.03)^{\text {ffhig }}$ & $1.37(0.02)^{\mathrm{b}}$ & $0.97(0.03)^{\mathrm{ef}}$ \\
\hline PP & 100 & 10 & $0.47(0.04)^{b c}$ & $0.47(0.05)^{\text {stu }}$ & $1.15(0.04)^{\mathrm{de}}$ & $0.78(0.04)^{\mathrm{ih}}$ \\
\hline PP & 100 & 12 & $0.35(0.02)^{e f}$ & $0.22(0.01)^{x w}$ & $0.99(0.01)^{\mathrm{jki}}$ & $0.47(0.04)^{\mathrm{ml}}$ \\
\hline PP & 100 & 14 & $0.01(0.005)^{\mathrm{mn}}$ & $0.08(0.02)^{z}$ & $0.47(0.01)^{\mathrm{ut}}$ & $0.03(0.002)^{\mathrm{op}}$ \\
\hline LT & 75 & 2 & $0.01(0.005)^{n}$ & $0.01(0.001)^{z}$ & $0.01(0.004)^{x y}$ & $0.03(0.01)^{\mathrm{op}}$ \\
\hline LT & 75 & 4 & $0.05(0.01)^{\mathrm{mn}}$ & $0.23(0.02)^{w x}$ & $0.08(0.01)^{x}$ & $0.24(0.03)^{n}$ \\
\hline LT & 75 & 6 & $0.14(0.04)^{j \mathrm{k}}$ & $0.76(0.02)^{j \mathrm{jmk}}$ & $0.25(0.02)^{w v}$ & $0.70(0.03)^{\mathrm{jj}}$ \\
\hline LT & 75 & 8 & $0.32(0.02)^{g \text { fh }}$ & $0.84(0.02)^{\text {ponq }}$ & $0.84(0.03)^{j / \mathrm{km}}$ & $0.93(0.04)^{\mathrm{feg}}$ \\
\hline LT & 75 & 10 & $0.48(0.01)^{\mathrm{a}}$ & $0.95(0.03)^{j \text { jhigk }}$ & $0.82(0.02)^{\mathrm{onm}}$ & $0.84(0.04)^{\text {fhg }}$ \\
\hline LT & 75 & 12 & $0.23(0.01)^{\mathrm{ji}}$ & $0.67(0.02)^{r a}$ & $0.72(0.02)^{r s q p}$ & $0.45(0.03)^{\mathrm{m}}$ \\
\hline LT & 75 & 14 & $0.08(0.005)^{\mathrm{Im}}$ & $0.41(0.005)^{\mathrm{w}}$ & $0.35(0.02)^{v}$ & $0.15(0.02)^{\circ}$ \\
\hline LT & 100 & 2 & $0.01(0.005)^{n}$ & $0.37(0.02)^{z}$ & $0.62(0.05)^{5}$ & $0.03(0.003)^{\mathrm{op}}$ \\
\hline LT & 100 & 4 & $0.27(0.02)^{\text {ih }}$ & $1.06(0.07)^{\mathrm{ef}}$ & $1.18(0.03)^{\text {dce }}$ & $0.71(0.03)^{i j}$ \\
\hline LT & 100 & 6 & $0.41(0.03)^{\text {bcde }}$ & $1.31(0.03)^{\mathrm{ab}}$ & $1.01(0.07)^{\text {ghi }}$ & $0.96(0.05)^{\text {ef }}$ \\
\hline LT & 100 & 8 & $0.39(0.06) \mathrm{d}^{\mathrm{ef}}$ & $1.28(0.06)^{b c}$ & $0.58(0.07)^{t}$ & $0.86(0.05)^{\text {fhg }}$ \\
\hline LT & 100 & 10 & $0.38(0.03)^{\text {cde }}$ & $0.97(0.02)^{\text {fhig }}$ & $0.24(0.03)^{w}$ & $0.47(0.02)^{\mathrm{ml}}$ \\
\hline LT & 100 & 12 & $0.02(0.01)^{n}$ & $0.17(0.02)^{\mathrm{Inmk}}$ & $0.10(0.01)^{x}$ & $0.11(0.01)^{\circ}$ \\
\hline LT & 100 & 14 & $0.006(0.01)^{n}$ & $0.06(0.02)^{z}$ & $0.06(0.01)^{x y}$ & $0.05(0.01)^{\mathrm{op}}$ \\
\hline
\end{tabular}


Table 3 Effect of biological elicitors on Gyrinops walla calli (Continued)

\begin{tabular}{|c|c|c|c|c|c|c|}
\hline \multirow{2}{*}{$\begin{array}{l}\text { Type of } \\
\text { elicitation }\end{array}$} & \multirow{2}{*}{$\begin{array}{l}\text { Concentration } \\
\text { (mg/L) }\end{array}$} & \multirow{2}{*}{$\begin{array}{l}\text { Incubation } \\
\text { period } \\
\text { (weeks) }\end{array}$} & \multicolumn{4}{|c|}{ Area percentage of } \\
\hline & & & $\mathrm{Y}$-Selinene & $\beta$-Caryophyllene & a-Cardinol & a-Guaiene \\
\hline TV & 75 & 2 & $0.01(0.005)^{n}$ & $0.06(0.01)^{z}$ & $0.06(0.01)^{x y}$ & $0.13(0.02)^{\circ}$ \\
\hline TV & 75 & 4 & $0.09(0.005)^{\prime}$ & $0.68(0.02)^{\text {prq }}$ & $0.66(0.01)^{\mathrm{rs}}$ & $0.80(0.03)^{\mathrm{ih}}$ \\
\hline TV & 75 & 6 & $0.23(0.02)^{\mathrm{ji}}$ & $0.89(0.06)^{j \text { limk }}$ & $1.04(0.06)^{g^{f}}$ & $1.02(0.06)^{e}$ \\
\hline TV & 75 & 8 & $0.35(0.02)^{\mathrm{efg}}$ & $0.95(0.04)^{\text {fhig }}$ & $1.22(0.02)^{\mathrm{cd}}$ & $1.47(0.06)^{c}$ \\
\hline TV & 75 & 10 & $0.38(0.02)^{\mathrm{ef}}$ & $0.96(0.03)^{\text {jhigk }}$ & $1.01(0.005)^{g h i}$ & $1.17(0.05)^{d}$ \\
\hline TV & 75 & 12 & $0.33(0.01)^{g f h}$ & $0.45(0.02)^{\text {ponq }}$ & $0.86(0.01)^{\mathrm{Inm}}$ & $0.79(0.05)^{\text {ih }}$ \\
\hline TV & 75 & 14 & $0.08(0.01)^{\operatorname{lmn}}$ & $0.21(0.01)^{\mathrm{xw}}$ & $0.44(0.02)^{\mathrm{ut}}$ & $0.29(0.05)^{n}$ \\
\hline TV & 100 & 2 & $0.01(0.005)^{n}$ & $0.01(0.004)^{z}$ & $0.01(0.003)^{x y}$ & $0.03(0.01)^{\mathrm{op}}$ \\
\hline TV & 100 & 4 & $0.05(0.01)^{\mathrm{mn}}$ & $0.23(0.02)^{x w}$ & $0.06(0.01)^{x y}$ & $0.28(0.06)^{n}$ \\
\hline TV & 100 & 6 & $0.22(0.02)^{j i}$ & $0.76(0.02)^{j \mathrm{lmk}}$ & $0.24(0.04)^{\mathrm{wv}}$ & $0.70(0.03)^{i j}$ \\
\hline TV & 100 & 8 & $0.32(0.02)^{\text {gfh }}$ & $0.84(0.02)^{\text {ponq }}$ & $0.92(0.05)^{j \mathrm{jkm}}$ & $0.93(0.05)^{\mathrm{feg}}$ \\
\hline TV & 100 & 10 & $0.48(0.01)^{\mathrm{a}}$ & $0.95(0.02)^{\text {jhik }}$ & $0.86(0.01)^{\mathrm{nm}}$ & $0.86(0.05)^{\text {fhg }}$ \\
\hline TV & 100 & 12 & $0.23(0.01)^{\mathrm{ji}}$ & $0.67(0.02)^{p r q}$ & $0.68(0.02)^{r s q}$ & $0.43(0.02)^{\mathrm{m}}$ \\
\hline TV & 100 & 14 & $0.08(0.01)^{\mathrm{mn}}$ & $0.41(0.005)^{\mathrm{w}}$ & $0.34(0.02)^{t}$ & $0.15(0.05)^{\circ}$ \\
\hline
\end{tabular}

\section{(a)}

(b)

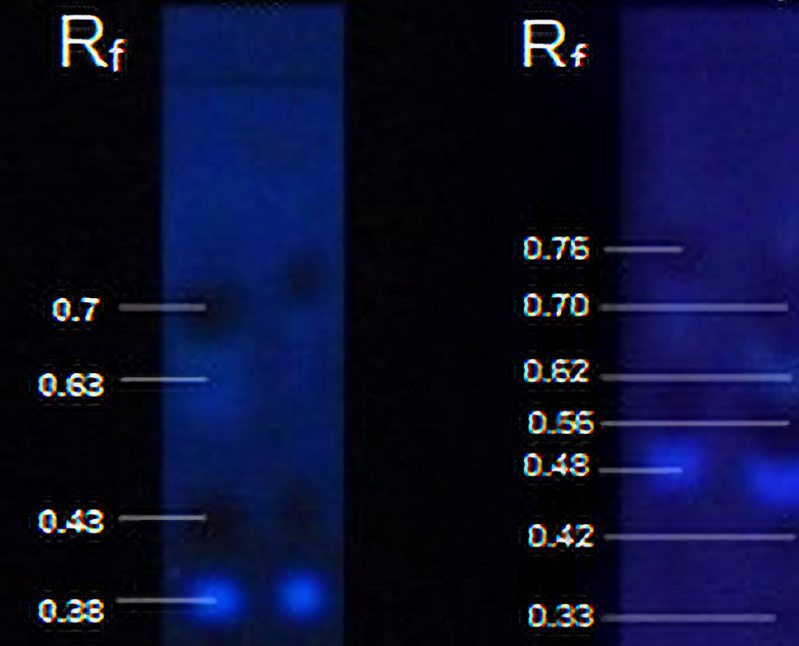

Fig. $11 \mathrm{TLC}$ profiles of biologically elicited G. walla cell suspension (a) L. theobromae (1) $8 \mathrm{mg} / \mathrm{L},(2) 10 \mathrm{mg} / \mathrm{L}$ and (b) P. parasitica (1) $6 \mathrm{mg} / \mathrm{L}$, (2) $8 \mathrm{mg} / \mathrm{L}$, (3) $10 \mathrm{mg} / \mathrm{L}$ on the 6 th hour 


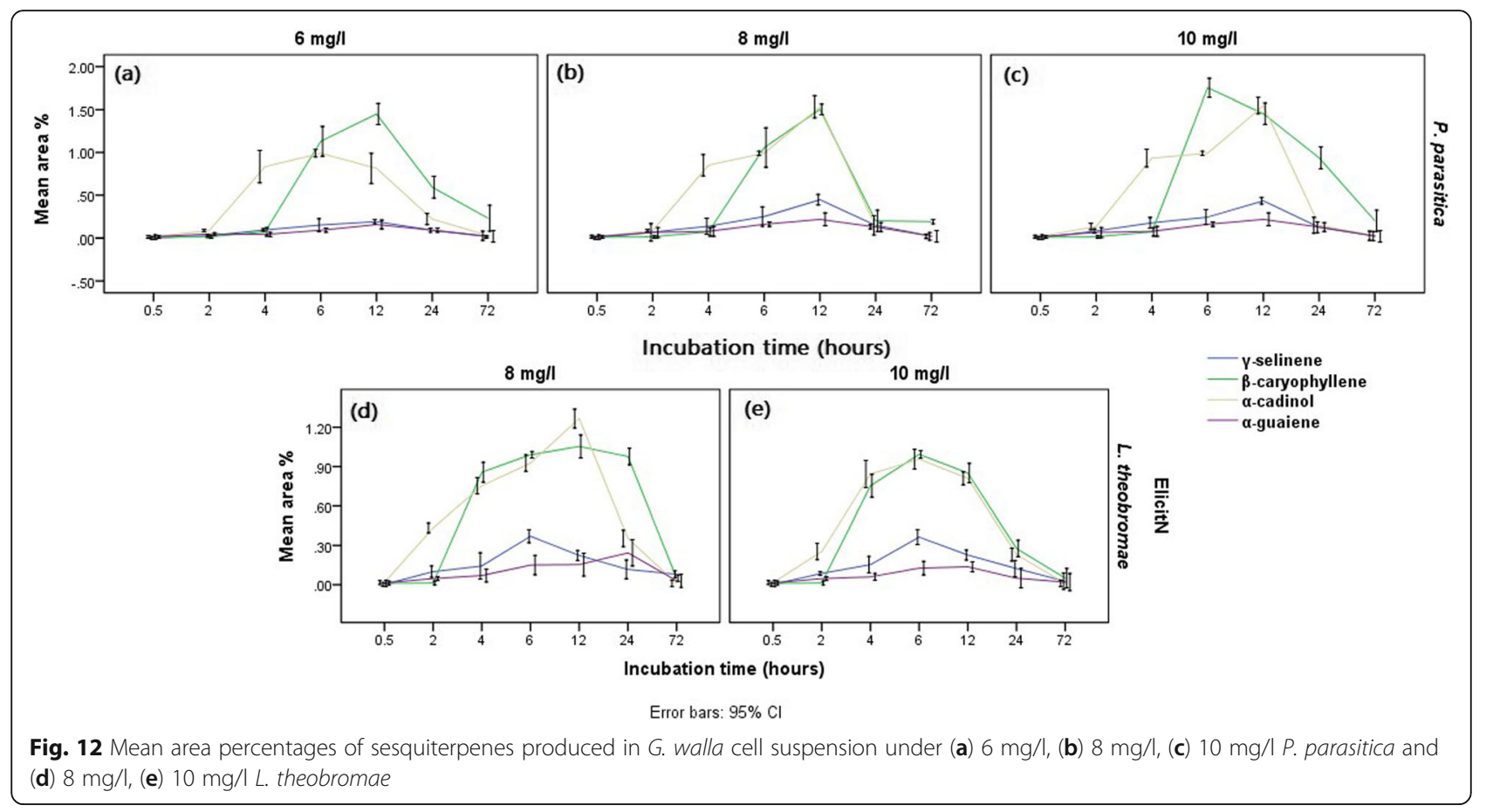

resulted in a similar effect on G. walla cell suspension (Table 4). Conversely, higher area percentages of sesquiterpenes were obtained for $8 \mathrm{mg} / \mathrm{L}$ Lasidiplodia theobromae on the 6th $(\gamma$-selinene $-0.37 \%$ and $\beta$ charyophllene $-0.99 \%), 12$ th $(\alpha$-cadinol $-1.26 \%)$ and 24th hour ( $\alpha$-guaiene $-0.24 \%)$. Similar to chemical elicitation of cell suspension culture, the area percentage of $\beta$-charyophllene and $\alpha$-cadinol were higher; meanwhile, minimum area percentages of $\gamma$-selinene and $\gamma$ guaiene were obtained with biological elicitation of $G$. walla cell suspension.

According to Fig. 13, two distinct behavioural patterns of sesquiterpenes were observed for G. walla calli which consisted of $\beta$-caryophyllene, $\alpha$-cadinol and $\alpha$-guaiene (pattern 1) and $\gamma$-selinene (pattern 2). Trendlines of sesquiterpenes in pattern 1 overlapped with each other while pattern 2 was proceeded distantly from pattern 1 . Comparatively, the area percentage of $\beta$-caryophyllene, $\alpha$-cadinol and $\alpha$-guaiene was higher than that of $\gamma$-selinene. Furthermore, trendlines of the sesquiterpenes showed an earlier production of $\alpha$-guaiene which eventually dropped while $\beta$-caryophyllene was increased on the 10th week. On the contrary, three behavioural patterns of sesquiterpenes were observed in G. walla cell suspension elicited with biological elicitors which consisted of $\alpha$-cadinol (pattern 1), $\beta$-caryophyllene (pattern 2) and, $\alpha$-guaiene and $\gamma$-selinene (pattern 3 ). Similar to the trendlines observed in chemically elicited cell suspensions, the area percentage of $\alpha$ cadinol was comparatively higher than that of biologically elicited calli. Trendlines of $\alpha$-guaiene and $\gamma$-selinene performed similarly.

\section{Discussion}

During the production of sesquiterpenes in artificially elicited callus and cell suspension cultures of G. walla, the peaks of different sesquiterpenes appeared and were rapidly attenuated, and the aroma simultaneously faded away in certain elicitation conditions after 8 weeks and $6 \mathrm{~h}$, respectively. This implies that different pathways of sesquiterpenes of highly volatile to less volatile compounds are involved and the volatile compounds might escape from the system immediately. Further, during the elicitation, interaction among the sesquiterpenes and the feedback mechanisms involved in inhibition and activation of enzyme systems through gene expression could be one of the plausible explanations of the transient appearance of volatile compounds. Various mechanisms have been put forwarded to explain these observations such as degradation by endogenous enzymes [12] and diffusion of the aromatic compounds into the air which supports the findings of the present study. In addition, results of the study suggested that the viability of the calli and cell suspension are essential in the production of sesquiterpenes. However, in the production of chromone compounds, cell viability does not play a major role. Okudera and Ito [12] are of the opinion that chromone derivatives are produced by the degradation of cell wall constituents by endogenous enzymes during the process of cell death and sesquiterpenes are compounds whose biosynthesis is induced by 
Table 4 Effect of biological elicitors on Gyrinops walla cell suspension

\begin{tabular}{|c|c|c|c|c|c|c|}
\hline \multirow{2}{*}{$\begin{array}{l}\text { Type of } \\
\text { elicitation }\end{array}$} & \multirow{2}{*}{$\begin{array}{l}\text { Concentration } \\
\text { (mg/L) }\end{array}$} & \multirow{2}{*}{$\begin{array}{l}\text { Incubation } \\
\text { period } \\
\text { (hours) }\end{array}$} & \multicolumn{4}{|c|}{ Area percentage of } \\
\hline & & & $\mathrm{Y}$-Selinene & $\beta$-Caryophyllene & a-Cardinol & a-Guaiene \\
\hline Control & 0 & 0 & $0.01(0.005)^{\mathrm{hi}}$ & $0.01(0.001)^{h}$ & $0.01(0.005)^{i}$ & $0.01(0.005)^{9}$ \\
\hline PP & 6.0 & 0.5 & $0.01(0.005)^{\mathrm{hi}}$ & $0.01(0.001)^{h}$ & $0.01(0.005)^{i}$ & $0.01(0.005)^{9}$ \\
\hline PP & 6.0 & 2 & $0.02(0.005)^{\mathrm{hi}}$ & $0.01(0.005)^{h}$ & $0.08(0.005)^{i}$ & $0.04(0.001)^{g f}$ \\
\hline PP & 6.0 & 4 & $0.09(0.005)^{g f}$ & $0.07(0.02)^{\mathrm{h}}$ & $0.83(0.07)^{d}$ & $0.04(0.01)^{g f}$ \\
\hline PP & 6.0 & 6 & $0.15(0.03)^{\mathrm{ed}}$ & $1.13(0.07)^{\mathrm{e}}$ & $0.99(0.01)^{c}$ & $0.09(0.01)^{d}$ \\
\hline PP & 6.0 & 12 & $0.19(0.01)^{d}$ & $1.45(0.05)^{c}$ & $0.81(0.07)^{\mathrm{de}}$ & $0.15(0.02)^{\mathrm{ct}}$ \\
\hline PP & 6.0 & 24 & $0.09(0.01)^{g f}$ & $0.59(0.05)^{\mathrm{e}}$ & $0.24(0.02)^{f}$ & $0.09(0.01)^{d}$ \\
\hline PP & 6.0 & 72 & $0.01(0.005)^{\mathrm{hi}}$ & $0.23(0.06)^{f}$ & $0.02(0.002)^{i}$ & $0.02(0.001)^{9}$ \\
\hline PP & 8.0 & 0.5 & $0.01(0.005)^{i}$ & $0.01(0.001)^{h}$ & $0.01(0.005)^{i}$ & $0.01(0.005)^{9}$ \\
\hline PP & 8.0 & 2 & $0.06(0.04)^{\mathrm{hgi}}$ & $0.01(0.005)^{h}$ & $0.08(0.005)^{i}$ & $0.06(0.02)^{\text {edf }}$ \\
\hline PP & 8.0 & 4 & $0.13(0.03)^{\text {edf }}$ & $0.07(0.02)^{h}$ & $0.85(0.05)^{d}$ & $0.07(0.02)^{\mathrm{ed}}$ \\
\hline PP & 8.0 & 6 & $0.25(0.04)^{c}$ & $1.05(0.09)^{b}$ & $0.99(0.01)^{c}$ & $0.16(0.01)^{\mathrm{b}}$ \\
\hline PP & 8.0 & 12 & $0.44(0.02)^{a}$ & $1.50(0.02)^{b}$ & $1.53(0.05)^{\mathrm{a}}$ & $0.21(0.03)^{\mathrm{a}}$ \\
\hline PP & 8.0 & 24 & $0.14(0.04)^{\text {edf }}$ & $0.20(0.005)^{f}$ & $0.14(0.01)^{\mathrm{h}}$ & $0.12(0.02)^{c}$ \\
\hline PP & 8.0 & 72 & $0.02(0.001)^{i}$ & $0.19(0.02)^{f}$ & $0.02(0.01)^{i}$ & $0.02(0.002)^{9}$ \\
\hline PP & 10.0 & 0.5 & $0.003(0.001)^{i}$ & $0.01(0.001)^{h}$ & $0.01(0.005)^{i}$ & $0.01(0.002)^{9}$ \\
\hline PP & 10.0 & 2 & $0.08(0.01)^{\mathrm{hgf}}$ & $0.01(0.005)^{h}$ & $0.13(0.01)^{\mathrm{h}}$ & $0.06(0.02)^{\text {edf }}$ \\
\hline PP & 10.0 & 4 & $0.17(0.02)^{d}$ & $0.07(0.02)^{h}$ & $0.93(0.04)^{c}$ & $0.07(0.02)^{\mathrm{ed}}$ \\
\hline PP & 10.0 & 6 & $0.24(0.03)^{c}$ & $1.75(0.04)^{\mathrm{a}}$ & $0.99(0.01)^{c}$ & $0.16(0.01)^{b}$ \\
\hline PP & 10.0 & 12 & $0.43(0.01)^{\mathrm{ab}}$ & $1.45(0.05)^{d}$ & $1.54(0.03)^{\mathrm{a}}$ & $0.21(0.03)^{a}$ \\
\hline PP & 10.0 & 24 & $0.12(0.02)^{\text {edf }}$ & $0.93(0.05)^{d}$ & $0.14(0.03)^{h}$ & $0.12(0.02)^{c}$ \\
\hline PP & 10.0 & 72 & $0.02(0.002)^{i}$ & $0.20(0.05)^{f}$ & $0.02(0.001)^{i}$ & $0.02(0.004)^{9}$ \\
\hline LT & 8.0 & 0.5 & $0.01(0.005)^{i}$ & $0.01(0.003)^{h}$ & $0.01(0.005)^{i}$ & $0.01(0.004)^{9}$ \\
\hline LT & 8.0 & 2 & $0.10(0.01)^{\text {egf }}$ & $0.01(0.005)^{h}$ & $0.43(0.01)^{f}$ & $0.04(0.005)^{e f}$ \\
\hline LT & 8.0 & 4 & $0.14(0.04)^{\text {edf }}$ & $0.85(0.03)^{f}$ & $0.75(0.02)^{\text {fh }}$ & $0.07(0.02)^{\mathrm{ed}}$ \\
\hline LT & 8.0 & 6 & $0.37(0.02)^{b}$ & $0.99(0.01)^{d}$ & $0.92(0.02)^{c}$ & $0.15(0.03)^{\mathrm{cb}}$ \\
\hline LT & 8.0 & 12 & $0.22(0.01)^{c}$ & $1.05(0.03)^{\mathrm{e}}$ & $1.26(0.02)^{b}$ & $0.15(0.03)^{\mathrm{cb}}$ \\
\hline LT & 8.0 & 24 & $0.11(0.02)^{\text {edf }}$ & $0.97(0.02)^{d}$ & $0.35(0.02)^{f}$ & $0.24(0.04)^{a}$ \\
\hline LT & 8.0 & 72 & $0.08(0.01)^{\text {hgf }}$ & $0.45(0.05)^{\text {de }}$ & $0.01(0.001)^{i}$ & $0.03(0.005)^{9}$ \\
\hline LT & 10.0 & 0.5 & $0.01(0.005)^{i}$ & $0.01(0.001)^{h}$ & $0.01(0.004)^{i}$ & $0.01(0.005)^{9}$ \\
\hline LT & 10.0 & 2 & $0.08(0.005)^{\text {hgf }}$ & $0.01(0.005)^{h}$ & $0.25(0.02)^{h}$ & $0.04(0.001)^{e f}$ \\
\hline LT & 10.0 & 4 & $0.15(0.02)^{\mathrm{ed}}$ & $0.75(0.03)^{\mathrm{e}}$ & $0.84(0.04)^{c d}$ & $0.06(0.01)^{\text {edf }}$ \\
\hline LT & 10.0 & 6 & $0.36(0.02)^{b}$ & $0.99(0.01)^{d}$ & $0.95(0.03)^{c}$ & $0.12(0.02)^{c}$ \\
\hline LT & 10.0 & 12 & $0.22(0.01)^{c}$ & $0.85(0.03)^{g f}$ & $0.81(0.02)^{d}$ & $0.13(0.01)^{\mathrm{ch}}$ \\
\hline LT & 10.0 & 24 & $0.12(0.02)^{\text {edf }}$ & $0.27(0.02)^{\mathrm{fg}}$ & $0.23(0.02)^{h}$ & $0.05(0.003)^{\mathrm{ec}}$ \\
\hline LT & 10.0 & 72 & $0.02(0.002)^{i}$ & $0.05(0.03)^{\mathrm{h}}$ & $0.01(0.003)^{i}$ & $0.02(0.005)^{9}$ \\
\hline
\end{tabular}

PP, Phaeocremonium parasitica; TV, Trichoderma viride; and $L T$, Lasidiplodia theobromae. The mean values are followed by standard deviation within parentheses. The same letter along the columns indicates no statistically significant difference at $p \leq 0.05$

signal transducers which happens when cells are viable. This finding supports the observations of the present study regarding the appearance of sesquiterpenes when calli/cell suspensions are viable. Moreover, the findings of the present study indicate that the maximum incubation period for G. walla calli and cell suspension are 8 or 10 weeks and $12 \mathrm{~h}$, respectively. In the present study, sesquiterpenes $\alpha$-cadinol, $\beta$-caryophyllene, $\alpha$ guaiene and $\gamma$-selinene, which are identical to that of the wood, were obtained from the three elicitation 

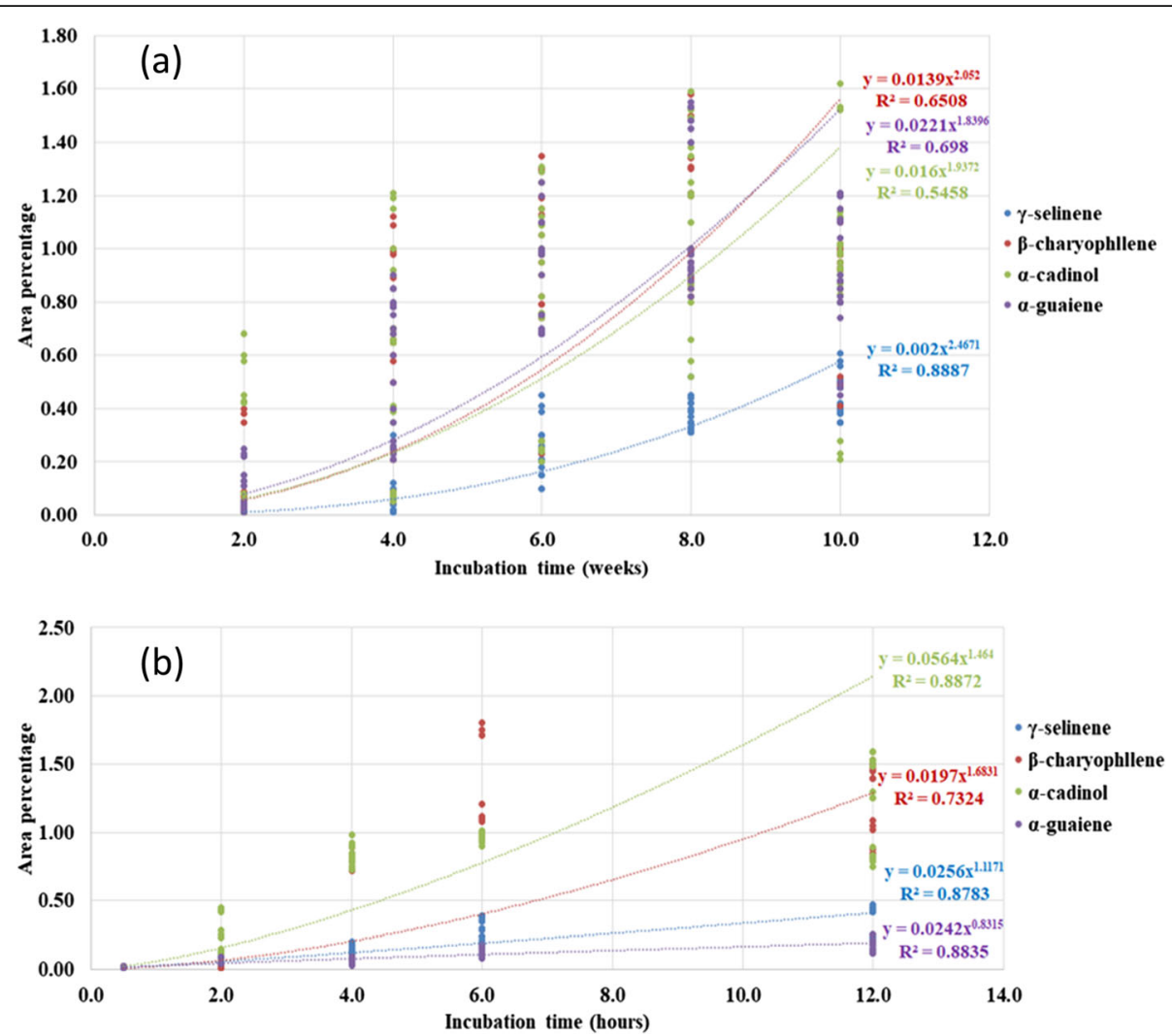

Fig. 13 Trends of area percentages of biologically elicited (a) G. walla calli and (b) cell suspension. The graphs include the data up to the maximum area percentage of sesquiterpenes

methods. Moreover, by observing Figs. 6 and 13, it can be concluded that different elicitation methods yield sesquiterpenes in different compositions. All these findings imply the potential of artificially eliciting calli and cell suspensions of $G$. walla to induce synthesis of sesquiterpenes.

G. walla callus and cell suspension cultures treated with SA and MJ showed an enhancement of sesquiterpene content. The addition of SA and MJ yielded higher area percentages of $\alpha$-cadinol and $\beta$-caryophyllene, and lower area percentages of $\alpha$-guaiene and $\gamma$-selinene were observed in both G. walla calli and cell suspension. SA and $\mathrm{MJ}$ are well-known as signal transducers in response to wounding and pathogens [23]. Therefore, the occurrence of sesquiterpenes and associations between these sesquitepenes were supported by the fact that SA and MJ play important roles in plant defence, in which a variety of defence genes are exposed through "cross-talking" of these signal transducers [24, 25]. Several studies on Aquilaria cell cultures have shown that MJ and SA elicitation enhance the production of sesquiterpenes. For instance, Kumeta and Ito, [26] showed that the production of sesquiterpene compounds, $\alpha$-humulene and guaiene derivatives, was induced by externally added MJ in Aquilaria cell suspensions. In their study, humulene and guaiene have different skeletal types, and their relative amounts in the suspension cells changed during the course of the culture period, which may mean that at least two different types of sesquiterpene cyclases were induced with different kinetics in Aquilaria suspension cells by MJ stimulation. The addition of MJ and SA to the callus and cell suspension cultures resulted in maximum sesquiterpene production, which indicated the potential of abiotic elicitors SA and MJ for the enhancement of sesquiterpene biosynthesis in callus and cell suspension cultures of G. walla.

The carbohydrate homogenates of Phaeocremonium parasitica, Trichoderma viride and Lasidiplodia theobromae fungal strains with their higher concentrations were effective in the production of sesquiterpenes in callus and cell suspension cultures of G. walla. Particularly, in G. walla calli, three sesquiterpenes, except $\gamma$-selinene, occurred in similar quantities indicating the productivity and efficiency of biological elicitation to G. walla calli compared to other elicitation methods. In order to achieve the maximum induction of sesquiterpene synthesis, both the dose of the elicitor and the age of culture to be elicited needed to be optimized. These findings are supported by similar studies conducted on several other metabolite and plant cell systems, e.g., 
shikonin production by Lithospermum erythrorhizon [27], shikonin by Arnebia euchroma [28], and taxoids by Taxas cuspidate [29]. The requirement of optimal dose suggests that at elicitor doses smaller than the optimum, the elicitor-binding sites in the cells were still not fully utilized for activating the secondary metabolite synthesis, while excessive doses caused a deleterious effect on the cells' biosynthetic activity [30].

Various fungal elicitors, including cell wall fragments, polysaccharides, oligosaccharides and glycoproteins, have also been used in the induction of secondary metabolite production with many other plant cell species [27, 31]. However, it is still not well-understood how these elicitors mediated the secondary metabolite biosynthesis in plant cells. Some recent studies on one class of putative elicitors, oligoglucosides, suggested that elicitors first bind to certain proteins (the elicitor-binding proteins) in the cell membrane, which might function as signal transduction receptors to initiate a series of subsequent defence-related responses [32]. These responses may include the synthesis and incorporation of hydroxyproline-rich glycoproteins, cellulose callose and polymers, the production of phytoalexins, and the enhanced expression of genes encoding enzymes such as phenylalanine ammonia-lyase. However, the relevance of these responses to the enhancement of secondary metabolite synthesis remains to be discovered.

Calli and cell suspensions of several genera of family Thymelaeaceae have been subjected to biological elicitation for the production of sesquiterpenes, including Aquilaria sinensis induced by Lasiodiplodia theobromae [13] and Aquilaria malaccensis by Trichoderma [16]. However, as far as G. walla is concerned, there is scarcity in published records for biological elicitation of G. walla calli and cell suspension.

\section{Conclusion}

The chemical, biological, elicitation of calli and cell suspension of G. walla proved the feasibility of production of four sesquiterpenes ( $\gamma$-selinene, $\alpha$-guaiene, $\beta$ caryophyllene and $\alpha$-cadinol) under laboratory condition. Future perspective studies are required to affirm the feasibility of mass production of agarwood resinous substances using pilot-scale systems such as bioreactors with hairy root culture.

\section{Abbreviations}

BAP: 6-Benzylaminopurine; GC-MS: Gas chromatography-mass spectroscopy; LT: Lasidiplodia theobromae; MJ: Methyl jasmonate; MSM: Murashige and Skoog medium; NAA: 1-Naphthaleneacetic acid; PP: Phaeocremonium parasitica; PDA: Potato dextrose agar; SA: Salicylic acid; TTC: 2, 3, 5Triphenyltetrazolium chloride; TLC: Thin-layer chromatography;

TV: Trichoderma viride; UV: Ultraviolet

\section{Acknowledgements}

The technical assistance given by the staff of the Industrial Technology Institute, Malabe, Botany and Chemistry Research Laboratories of the Open University of Sri Lanka, Nugegoda, is highly acknowledged.

\section{Authors' contributions}

SM carried out the fieldwork as well as the data processing and the writing of the paper. SS was responsible for corrections within the paper. SRW was responsible for corrections in between and provided advice. CR provided additional helpful information regarding chemical analysis. All authors contributed critically to the drafts and gave final approval for publication.

\section{Funding}

The OUSL Competitive Research Grant - 2016 (OU201601) supported the research financially by providing funds to purchase chemicals and equipment needed to conduct the research and analyse extracted chemicals through GC-MS

\section{Availability of data and materials \\ N/A}

\section{Declarations}

Ethics approval and consent to participate N/A

\section{Consent for publication}

N/A

\section{Competing interests}

The authors declare that they have no competing interests.

\section{Author details}

'Department of Botany, The Open University of Sri Lanka, Nawala, Sri Lanka. ${ }^{2}$ Department of Chemistry, The Open University of Sri Lanka, Nawala, Sri Lanka.

Received: 18 January 2021 Accepted: 31 May 2021

Published online: 03 September 2021

\section{References}

1. Herber BE, Metcalfe CR, Chalk L (1988) Anatomy of the dicotyledons. Systematic anatomy of the leaf and stem, with a brief history of the subject, vol Volume I, 2nd edn

2. Compton JGS, Zich FA (2002) Gyrinops ledermannii (Thymalaeaceae), being an agarwood producing species prompts call for further examination of taxonomic implications in the generic delimitation between Aquilaria and Gyrinops. Flora Malesiana Bull 13(1):61-66

3. Nobuchi T, Siripatanadilok S (1991) Preliminary observation of Aquilaria crassna wood associate with the formation of aloeswood. Bull Kyoto Univ Forests 63:226-235

4. Takemoto H, Ito M, Shiraki T, Yagura T, Honda G (2008) Sedative effects of vapor inhalation of agarwood oil and spikenard extract and identification of their active components. J Nat Med 62(1):41-46. https://doi.org/10.1007/s1141 8-007-0177-0

5. www.dailynews.Ik. Retrived July 7, 2019 from www.dailynews.lk/2018/06/28/ local/155233/dubai-bound-passenger-nabbed-walla-patta?page $=11$.

6. UNEP-WCMC (2019) CITES trade statistics derived from the CITES Trade Database. Retrieved 15/09/2019, from UNEP-World Conservation Monitoring Centre http://trade.cites.org/

7. MOE (2012) The Notational Red List 2012 of Sri Lanka. Conservation status of the Fauna and Flora. Ministry of Environment, Colombo, Sri Lanka VIII +476

8. Karuppusamy S (2009) A review on trends in production of secondary metabolites from higher plants by in vitro tissue, organ and cell cultures. Jed Plant Res 3(13):1222-1239

9. Lila KM (2005) Valuable secondary products from in vitro culture, Secondary Products In Vitro. CRC Press LLC

10. Vijayasree N, Udayasri P, Aswani KY, Ravi BB, Phani KY, Vijay VM (2010) Advancements in the production of secondary metabolites. J Nat Prod 3: $112-123$ 
11. Qi SY, He ML, Lin LD, Zhang CH, Hu L, Zhang HZ (2005) Production of 2-(2phenylethyl) chromones in cell suspension cultures of Aquilaria sinensis. Plant Cell Tissue Organ Cult 83(2):217-221. https://doi.org/10.1007/s11240-005-5479-x

12. Okudera $Y$, Ito M (2009) Production of agarwood fragrant constituents in Aquilaria calli and cell suspension cultures. Plant Biotechnol 26(3):307-315. https://doi.org/10.5511/plantbiotechnology.26.307

13. Zhang Z, Han XM, Wei JH, Xue J, Yang Y, Liang L, Gao ZH (2014) Compositions and antifungal activities of essential oils from agarwood of Aquilaria sinensis (Lour.) Gilg induced by Lasiodiplodia theobromae (Pat.) Griffon. \& Maubl. J Braz Chem Soc 25(1):20-26

14. Crous PW, Gams W, Wingfield MJ, Van Wyk PS (1996) Phaeoacremonium gen. nov. associated with wilt and decline diseases of woody hosts and human infections. Mycologia 88(5):786-796. https://doi.org/10.1080/00275514.1996.12026716

15. Sangareswari M, Parthiban KT, Kanna SU, Karthiba L, Saravanakumar D (2016) Fungal microbes associated with agarwood formation. Am J Plant Sci 7(10):1445-1452. https://doi.org/10.4236/ajps.2016.710138

16. Jayaraman S, Mohamed R (2015) Crude extract of Trichoderma elicits agarwood substances in cell suspensioculture of the tropical tree, Aquilaria malaccensis Lam. Turk J Agric For 39(2):163-173. https://doi.org/10.3906/tar-1404-63

17. Munasinghe SP, Somaratne S, Weerakoon SR, Ranasinghe C (2020) Prediction of chemical composition for callus production in Gyrinops walla Gaetner through machine learning. Inform Process Agric 7(4):511-522. https://doi.org/10.1016/j.inpa.2019.12.001

18. Duncan DR, Widholm JM (1990) Measurements of viability suitable for plant tissue cultures. In: Plant cell and tissue culture. Humana Press, pp 29-37

19. Mustafa NR, De Winter W, Van Iren F, Verpoorte R (2011) Initiation, growth and cryopreservation of plant cell suspension cultures. Nat Protoc 6(6):715742. https://doi.org/10.1038/nprot.2010.144

20. Ito M, Okimota KL, Yagura T, Honda G, Kiuchi F, Shimada Y (2005) Induction of sesquiterpenoid production by methyl jasmonate in Aquilaria sinensis cell suspension culture. Journal of Essentila oil Research 17(20):175-180

21. Dubois M, Gilles K, Hamilton J, Rebers P, Smith F (1956) Colorimetric method based on phenol sulfuric acid. Anal Chem 28:356

22. Jain SC, Pancholi B, Jain R (2012) In-vitro callus propagation and secondary metabolite quantification in Sericostoma pauciflorum. Iran J Pharm Res 11(4):1103

23. Shah J (2003) The salicylic acid loop in plant defense. Curr Opin Plant Biol 6(4):365-371. https://doi.org/10.1016/S1369-5266(03)00058-X

24. Felton GW, Korth KL (2000) Trade-offs between pathogen and herbivore resistance. Curr Opin Plant Biol 3(4):309-314. https://doi.org/10.1016/S13695266(00)00086-8

25. Reymond P, Farmer EE (1998) Jasmonate and salicylate as global signals for defense gene expression. Curr Opin Plant Biol 1(5):404-411. https://doi.org/1 0.1016/S1369-5266(98)80264-1

26. Kumeta $Y$, Ito M (2010) Characterization of $\delta$-guaiene synthases from cultured cells of Aquilaria, responsible for the formation of the sesquiterpenes in agarwood. Plant Physiol 154(4):1998-2007. https://doi. org/10.1104/pp. 110.161828

27. Chang HN, Sim SJ (1994) Increasing secondary metabolite production in plant cell cultures with fungal elicitors. Biotechnological applications of plant cultures. CRC Press, Boca Raton, Fla, pp 23-37

28. Fu XQ, Lu DW (1999) Stimulation of shikonin production by combined fungal elicitation and in situ extraction in suspension cultures of Arnebia euchroma. Enzym Microb Technol 24(5-6):243-246. https://doi.org/10.1016/ S0141-0229(98)00104-5

29. Ketchum RE, Rithner CD, Qiu D, Kim YS, Williams RM, Croteau RB (2003) Taxus metabolomics: methyl jasmonate preferentially induces production of taxoids oxygenated at C-13 in Taxus $\times$ media cell cultures. Phytochemistry 62(6):901-909. https://doi.org/10.1016/50031-9422(02)00711-2

30. Wang C, Wu J, Mei X (2001) Enhancement of taxol production and excretion in Taxus chinensis cell culture by fungal elicitation and medium renewal. Appl Microbiol Biotechnol 55(4):404-410. https://doi.org/10.1007/ s002530000567

31. DiCosmo F, Misawa M (1985) Eliciting secondary metabolism in plant cell cultures. Trends Biotechnol 3(12):318-322. https://doi.org/10.1016/01677799(85)90036-8

32. Ebel J, Mithöfer A (1998) Early events in the elicitation of plant defence. Planta 206(3):335-348. https://doi.org/10.1007/s004250050409

\section{Publisher's Note}

Springer Nature remains neutral with regard to jurisdictional claims in published maps and institutional affiliations.

\section{Submit your manuscript to a SpringerOpen ${ }^{\odot}$ journal and benefit from:}

- Convenient online submission

- Rigorous peer review

- Open access: articles freely available online

High visibility within the field

- Retaining the copyright to your article

Submit your next manuscript at $\boldsymbol{\nabla}$ springeropen.com 